University of Massachusetts Amherst

ScholarWorks@UMass Amherst

Doctoral Dissertations 1896 - February 2014

1917

\title{
A study of the sulphur supply of soils and its relation to plant growth
}

J. Stanley Cobb

Follow this and additional works at: https://scholarworks.umass.edu/dissertations_1

Part of the Plant Sciences Commons

\section{Recommended Citation}

Cobb, J. Stanley, "A study of the sulphur supply of soils and its relation to plant growth" (1917). Doctoral Dissertations 1896 - February 2014. 934.

https://doi.org/10.7275/qzjw-9585 https://scholarworks.umass.edu/dissertations_1/934

This Open Access Dissertation is brought to you for free and open access by ScholarWorks@UMass Amherst. It has been accepted for inclusion in Doctoral Dissertations 1896 - February 2014 by an authorized administrator of ScholarWorks@UMass Amherst. For more information, please contact scholarworks@library.umass.edu. 
$* \quad$ UMASS/AMHERST

ᄂ

312066023042164 

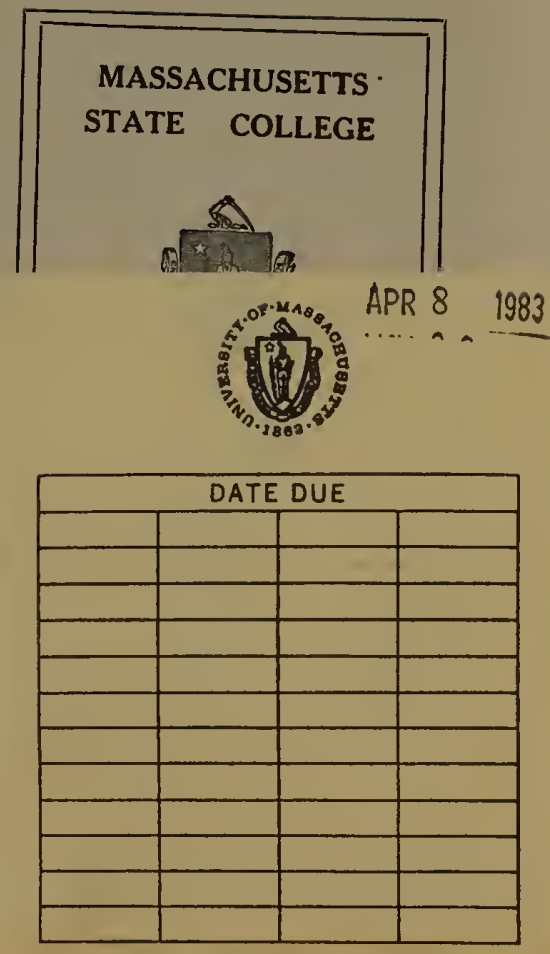

UNIV. OF MASSACHUSETTS/AMHERST LIBRARY

MORR

LD

3234

M268

1917

C653 


\section{AGRONOMY DEPIRTIMENT}

A STUDY CF THE SULPHUR SUPPIY OF SOILS AID IIS PELATIOA LO PLANI GBOWTH

BI

J. STAULEY COBB

A THESIS

SUBLITIED FOR FHE DEGREE

OP

MSTER OF BCIENCE

MASSACHUSETSS AGRICULTURAI COLLEGE

AKCERST, MASSACHOSETTS.

June 15, 1917. 
Aoknowlederment

Acknowlodgement is gratefully given to Professors

S. B. Hasrall and Barl Jones for ald and corrections in

the preparation of this thesis, and to Dr. C. A. Peters for advice concerning the chemical work. 


\section{INTRODUCT ION}

The subject of the source of plant eroxth was one which occupled orly investigators for centurios and brought forth numerous theorles and explanations. The present problem of the plant physiologist, or rore correctly, the agronomist, is to keop the plant supplied with 1 ts source of growth in proper amounts and under proper conditions. Our knowledge of the elements necessary for plant growth we ove to the work of some early chemists and plant physiologists.

Theodore de Saussure in 1804 laid the foundation for future work by $h i s$ use of the quantitative statistical method. He found that the corpositiou of plant ash is not constant, but varies with the nature of the ooll and the stage of growth of the plant. However, he determined that it consists ohlefly of alkalis and phosphatee. Thus, from the first, phosphates were found to be highly important in plant growth.

Based on this work of de Saussure came the subsequent work of Bousgingault, Sprengel, Ilobig and Lawes and Gilbert. Up to 1840 (2) Boussingaut had conducted some fleld experirants which were a great improvement over the pot experimant conelusions of Davy. (4) Sprengel had studied the ash constituents of planta. But very little interest or oontroversy was started until Liobig publishod his radical theories in 1840 as "Chemistry in 1ts Application to Agr 1oulture and Physiology".

Llebif held that plant growth is directly proportioned to the amount of mineral plant food constituents in the so11, and that 
the nitrogen 1a obtalned from the air. Laves and Gilbort took excoption to Llobig'a theory and by experirants, publighed in the early Rothameted romo1rs, demonstrated that plants obtalnod most of their nitrogan from the soll.

Thme by 1855 the fundanental prinolplos of 8011 fortility as knom today zere oatablished. Lawos and ollbert had proved by long continued experiments that crope require phosphates and salts of the alxalls and also supply of some nitrogenous comyounds no nitrateo or annonium salts. Inguminous crops behavod abnormally. the oause of mich ras not then known. Theg also showed that the compostion of tho ash does not afford reliablo information as to tho emounts of onch constituent neoded. Turnips pore found to raquire lares amounts of phosphates for erowth although only a 1ittlo is present in their ash.

Llobig's list of the elements nocessary for plsnt eronth has since been confirmod by plant physlologlsts and they aro knom to be potassium, menesium, calcium, 1ron. Whosphorus, salfur. carbon, nitrogen, bydrogen and oxggen.

Of those the most important are nitrogen, phoephorus and potassinm. Nitrogen fe knomn to aid batorisily tho vegetutivo Frowth of tho plant and five it size and eubstance; phosphoras aldo in onsig root provth and in bringing on marity, and potasolum alds materially the formation of chlorophyll ard the manufacture of atarch.

They are also important from the standpolnt of the agrononist as rogards soll fert 11 ity booause they seem to be most often deficiont in the ooll ard mat be artifiolalls appliod to molntain plint Erowth. For this renoon they aro oallod tilo primury plant food eloments although no core leportant for plant growth than tho othere. The fact that they are rowoved from the soll ard the 
amounts removed has bean learned, as previously stated, by chom1cal analysea of the plants grown.

The object of this paper 18 to consider the possiblitty of sulphur'g boooing as important in soll fertilization as the above elersents and to discuss some means of supplying any possible deflofency of gulphur in the soll.

\section{The Importance of sulphur.}

In the experiments of plant physlologlats sulphur has always boen included in mineral plant nutrients but has been added as a salt with some neoessary basic element.

Loov eajs that sulphur as a mineral element 18 Hren no credit as funotioning for plant food. Sulphates are used but the base only 1 ( 7$)$ considered.

Dugear states that aulphur is important only as a corponent of albuminoldal compounds. It is required in such limited quantities that the seed mag furnish all needed for normal growth of plant for a considerable period.

Present anslyges of crops show it to be present in most crops In as large amounts as is phosphorus. Analyser of the plant ash for sulphur do not give the total amount present in the plant so 
that figures given by early inveatigators are worthless. An the improvement in method of analysis has brought out Areal sulphur content of plants. This is show by the comparison given in the table by Hart and Peterson. The percentage in the ash as determined by wolff is seen to be only one half and less than one half of the real content of the plant as determined by the peroxide method.

This knowledge of the large amounts of aulphur removed from the ooll by crope has lod to investigations of the possibility of a deficiency of oulphur in the soll. Hart and peterson published the first important work in this country and other experiment statlong have since made investigations.

Bogdanov in Russia before 1899 msde the errllest mention of the posalbilitg of sulphur becoming of practical importance in the 8011 by the exhaustion ofthe supply through cropping. He compared the mothods of Liebig, Carius, Stoeckhardt and Schraeder for determining arlphur in cereals, loguminous plants and boets. Using Liebig's method as the most accurate and gimple ho found noar18 twelve times as much sulphur in the products examined as in their ash. Having observed beneficial effects of fertilizers containing sulphates, he concluded that sulphur may be of more benefit to plant growth than is usually as sumed.

\section{Sulphur Content of Crons.}

Fhosphorus is well known to be an important mineral plant food constituent in the soil. For this reason a comparison of the amounts of sulphur and phosphorus removed by crops and found in the soll will serve to show the possibility of sulphur's compoting with phosphorus as a limiting factor in the gield of some crops. 
The followine tablo 18 taken from the Fork of Fiart and (6)

peterson.

It ohovis well the relative arsounte of aulpiur

trioxide and phoaphorus pentoxide romoved frum the 8011 by tho came Para crops.

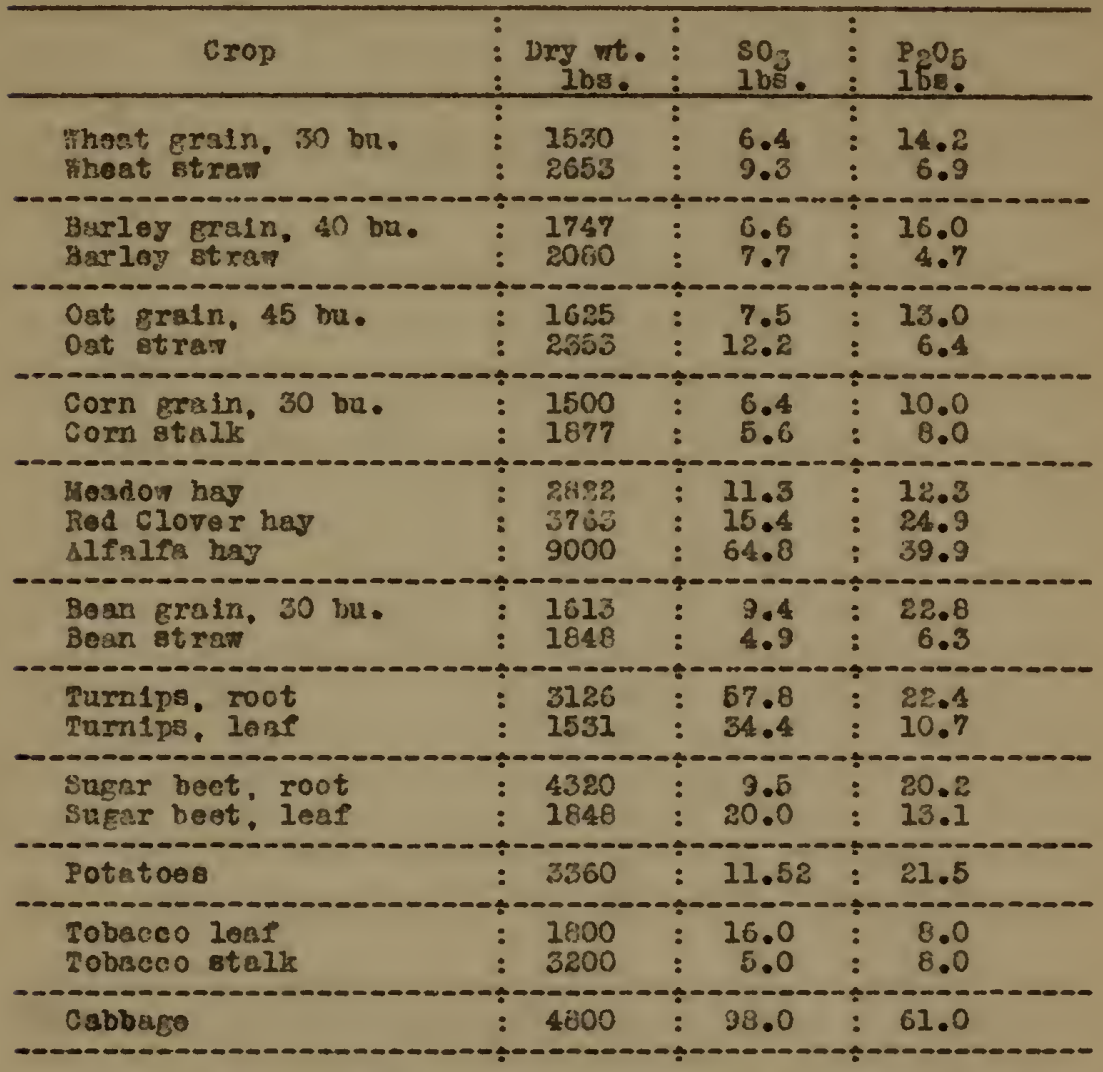

It cen really be seon that alfferent crope vary canaldorably in tholr enlnhur content. The cerealo and some othor crops romore 1088 sulphur than phophorus frow the so11. Certain crops Bnch as alfalf hay, cabbage and turnipe romovo rach more sulphur than phosphoras. 
The composition of the flants explains why some remove more aulphur than others. Sulphur is known to make up a large part of the protein compounds of plants and of certain volatile o1ls. Hence, plants such as the omclferae and alfalfa are alvays found to have a high sulphur contont. Proteins such as albumen and others are more or less important components of all plants and play a part in the life processes of tire plart. In this way sulphur functions in plant life. Therefore, the importance of a oupply being kept svailsble to the plant is apparent.

These crops include most of the common ones erovn on farms. From the table an idea can be obtained of the relatite amounts of asulphur removed by any crop. Plantg rich in protein and other compounds such as alfalfa and the cructferae always require more sulphur for their erowth than the cereals and other plants containing less salphur compounds.

\section{Sulphur content of Solle.}

Lumerous analyses of solls show the relative amounts of sulphur and phosphorus oontained. Clark states that the average percent of 3 lphur and phosphorus in the earth's crust is the 8 amo. $0.11 \%$, but the percentages in our cultivated and uncultivated flelda 1.1 vary considerably from that. Interestine data have been obtained from several states snd other pleces, some of which Fi11 bo quoted.

The average of annlyges of thirteen surface soils and sub(15)

80118 of the United states gives $\mathrm{SO}_{5}, 0.13 \%$ and $\mathrm{P}_{2} \mathrm{O}_{5}, 0.14,0$. (18)

H1Igara pives analyges of solls of aiffererti types, most of which show a greater content of phosphorus than of sulphur. With sors, howovor, the oprosite is true. This goes to show that the sulphur content of a soil depends more on its condition and 
treatment than on ang distinct oriein or type.

A strong acid solution of the soll was mato and the sulphur determined. The percentage of sulphux trioxide is probably low as the acid does not dissolve all the sulphur. The results obtained are as follows :

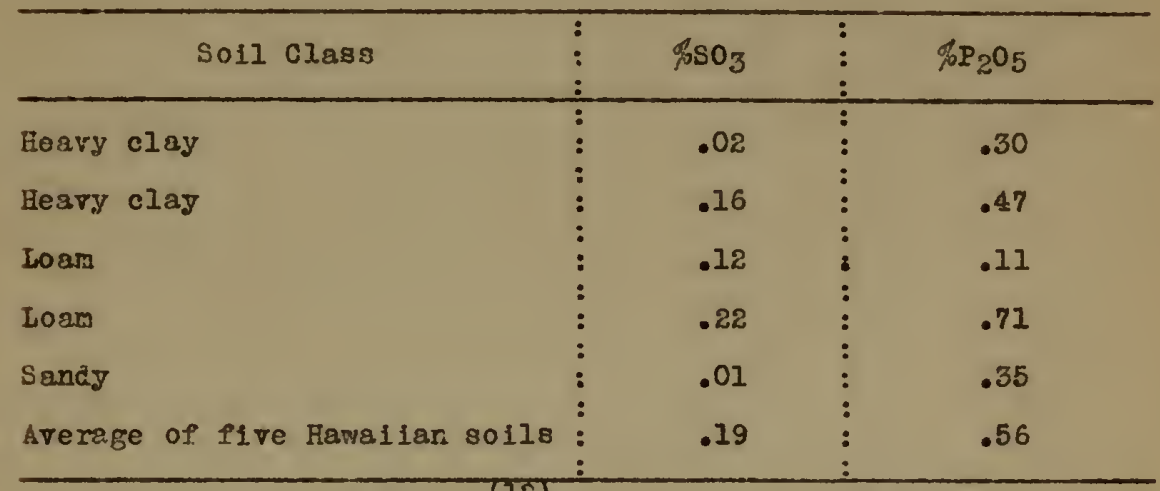

Dymond. Hughes and Jupe found English soile to contain less sulphur than phosphorus. kut the method for total sulpiur analysis was not used; so the actual sulphur content may have beon hicher. The sulphur and phosphorus content of sowe Kansas soils is (13) firen by Swanson and Miller as follows :

Total sulphur was obtained by the sodium peroxide fugion method. This method is used in alI morls hereinafter reported. Avorage percentagos in 13 virgin solls.

Lbs. per 2, 000,000 1bs, s011

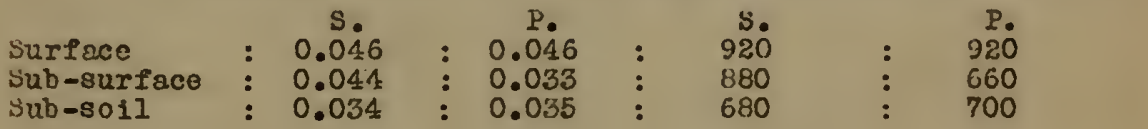

Average percentages in 16 cropped solls. Lbs. per 2, 000,000 1bs. 9011

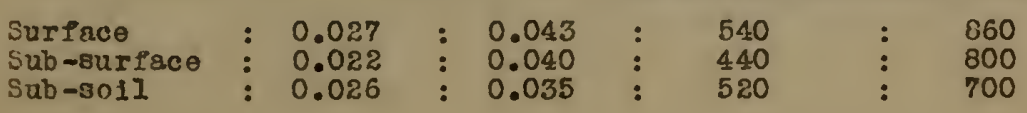


These figureg show that the umount of sulphux and phosphorus is about the ame in virgin soll but the amount of sulphur is less in cropped solly. ind icating a losg of eulphur through cultivation but no $108 \mathrm{~s}$ of phosphorue. The virgin and oropped so118 were not adjacont so no direot conclusions oan be dram regarding the loss of sulphur due to cultivation. but it plainly shows that cultivated solls have a smaller content of sulphur thun of phosphorus.

Analgses by the same mon of virein and cultivated solls similar and adjoining give ovidence as folloms : \% sulphur in virgin soll : \% sulphur in cropped soll : \% loss 0.044 0.062 $\vdots$ 0.027 0.036

They found that the loss of sulphur in cropped soils is greater than that of either nitrogen or carbon. The phosphorus and potash content tends to be higher in croppod than in virgin so11s.

\section{(14)}

Shedd roports comparative sulphur and phosphorus analyses of solis from several areas of the State of Kentucky. His mork 8hows higher amounts of phorphorus than of gulphur in all cases except one in both surface soil and sub-soil of virgin and oultivated soils. The loss due to cultivation is almost almays greater in the case of sulphur than phosphorus and while the phosphoris content is sometimes incressed by cultivetion, the sulphur content is always decreased escept in the cass of a changing river alluvial soil.

Brown and Kellogf give analyses of five goil areas which show greater amounts of phosphorus than of sulphur as follows : 
Sulnhur Ibs. per A. Phosyrorus

\begin{tabular}{|c|c|c|c|c|c|c|c|c|c|c|c|c|}
\hline \multirow{3}{*}{ So12 } & \multirow{2}{*}{\multicolumn{2}{|c|}{$\vdots$ Surface }} & \multicolumn{2}{|c|}{$\begin{array}{l}\text { sub- } \\
\text { : surface }\end{array}$} & \multirow{2}{*}{\multicolumn{2}{|c|}{ :Subsoil }} & \multirow{2}{*}{\multicolumn{2}{|c|}{$\begin{array}{l}:: \operatorname{surfaco} \\
::\end{array}$}} & \multicolumn{2}{|c|}{$\begin{array}{l}\text { Sub- } \\
\text { : surface }\end{array}$} & \multicolumn{2}{|c|}{ :Subso11 } \\
\hline & $:$ & & $:$ & & & & & & $:$ & & $:$ & \\
\hline & $:$ & & $:$ & & $:$ & & $::$ & & : & & : & \\
\hline Loess & : & 755 & : & 1239 & : & 1363 & $::$ & 1538 & : & 2697 & : & 3892 \\
\hline U1ssissipp1 & : & & : & & : & & $::$ & & : & & : & \\
\hline Looss & : & 719 & $:$ & 1073 & : & 1047 & $::$ & 1361 & : & 2204 & : & 3003 \\
\hline Southern & : & & : & & : & & $::$ & & : & & : & \\
\hline Iowa Loese & : & 770 & : & 1105 & : & 1055 & $::$ & 1368 & : & 2089 & : & 2972 \\
\hline "risc onsin & : & & : & & : & & $::$ & & : & & : & \\
\hline Drift & : & 938 & : & 1528 & : & 1327 & $::$ & 1395 & : & 2217 & : & 3253 \\
\hline Iowan & : & & : & & : & & $::$ & & : & & & \\
\hline Drift & : & 893 & : & 1207 & : & 855 & $::$ & 1289 & : & 2207 & $\vdots$ & 2889 \\
\hline
\end{tabular}

(6)

Hart and Peterson give analyses of 80118 of known history as comared with virgin solls. The cultivated solls show a decreaso in oulphur content even though light manuring had been pract 1 sed on the various crops.

Soll analyaes from rotation plots by Ames and Boztz show a slight decrease in sulphur content due to cultivation evan when some sulphur carrying fertilizers are used. A soll unfertilizod for sixteen Jears shows a loss of sixty pounds of sulphur per acre for that period. Other alfferenoes are not so marked but indicate a decrease in sulphur where crops have been growh.

\section{(18)}

The follozing analyses are of soll from plots of known treatment in the Pennsylaania and Rothamsted fertility tests.

Pennslgranie Plots

\begin{tabular}{|c|c|c|c|c|c|}
\hline Plot No. & $:$ & Treatment & $: \mathrm{sO}_{3}^{\%}$ & $\vdots$ & $2,000,000$ ibs. soil \\
\hline $\begin{array}{l}14 \\
16\end{array}$ & $\vdots$ & $f^{\text {Blank }}$ & $: .054$ & : & 1080 \\
\hline $\begin{array}{r}9 \\
17\end{array}$ & $\vdots$ & $\begin{array}{l}\text { (Acid phosphate } \\
\text { (Muriate of potash } \\
\text { (Blood }\end{array}$ & .965 & $\vdots$ & 1300 \\
\hline $\begin{array}{l}12 \\
35\end{array}$ & 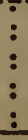 & $\begin{array}{l}\text { (Ground bone } \\
\text { (Murlate of potash } \\
\text { (Blood }\end{array}$ & $: 061$ & 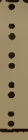 & 1220 \\
\hline
\end{tabular}


Here the no-treatment plots are found to be lon in sulphur content and the plot recelving acid phosphate as a sulphur carrier is higher in sulphur content than the one receiving other phosphate carriers.

Broadbalk Whoat Plots. Rothamsted.

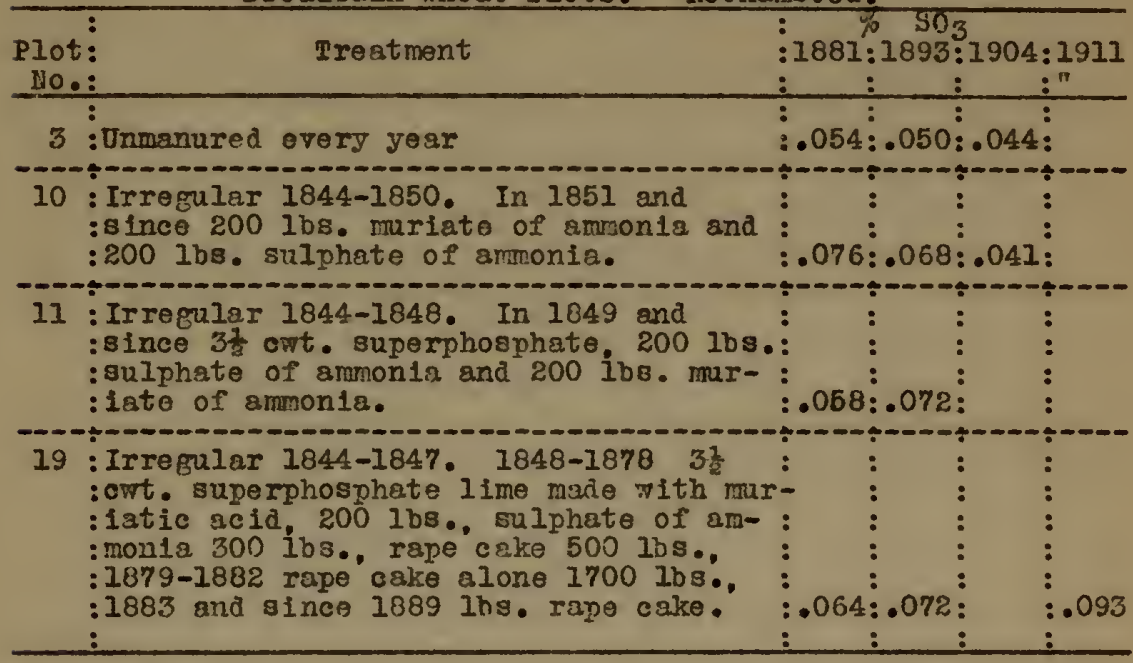

virgin soil. .091

Those analysos show a tendency for the percent of $\mathrm{SO}_{3}$ in the soll to decrease through cultivation without manure. W1th the use of some fertilizers the $\mathrm{SO}_{3}$ eontent of the soil $1 \mathrm{~s}$ soen to increase even above that of virgin soil.

From the above works the general conclusion may be dram that solls are found to be defloient in sulphur even more than they are in phosphorus. Also, a deoresse in the total sulphur content of the soll is seen to be brought about by cultivation and cropping. And, when properly fortilized, the sulphur content of the soll is maintalnod. This, then, may bo a general warning ; that sulphur may become a liaiting frctor in crop production unloss aupplied to the soll in fett1lizers of some sort. 
Forms of Sulphar in the Soll.

It Is one of nature's $\%$ isest provisions that plant food should be stored in the 8 oil in an insoluble condition and have to undergo changos hefore becoming goluble and available to the plant. Sulphur is no exception to this rule and, along with n1trogen, phosphorus and potessium exists in the soll both in a soluble and insoluble state.

Berthelot and Andre state that sulphur exists in the goil chlofly in three forms, sulphatos and sulphides, ethoroal sulphur, and organic compounds.

The sulphates are more or less soluble in the soll solution. Sulphides exist mostly in the form of pyrites and are slowly oxidized to sulphates. The organic matter resulting from manure applied to the soll and crop residues undergoes decay and oxidation of the sulphur present. Ethereal sulphur compounds probably reach the soll in manure from the urine of animals. The sulphur of organlc matter reaches the soil in tho form of complicated organic compounda.

(20)

Peterson states that sulphur occurs in plant and animal tissue chlefly in the form of proteins, volatile compounds, as the wustard 011s, and sulphates. He found that the amount of sulphates in plant t1asue varies 71 th tho soll supply and a vigorous growth way be mado where no sulphates are found in the tisaue. Therefore, the amount of sulphates furniahed to the soil in organ10 matter is negligible and the other forms of sulphur require changing.

Just what form or forms of sulphur are used by the plant has not boen dofiuitely proven but the evidence of experiments indicates 
that the sulphate form is necessary for suiphur assimilation by the plant. Sulphates are the final soluble form of alphur avallable to the plant. Applications of elomental sulphur have been

8 homn by Shedd to give greater incresses in plant growth than somo sulphites and sulphates. But he also shows that elementel sulphur 18 rapidly oxidized to sulphates in the soll. It may be true that the intermediate forms, before the sulphate form is reached, are taken up to a limited extent by plants, but probably not suffioientiy to be important. Analogous to this is the well knom formation and use of nitrates in the soll. The intermediate forms, as amonia and organic compounds, are thought to be usod by the plant to a linited extent.

The action of bateria in the transformation of aulphur is very important and has been shown by numerous investigators to be the chlef source of sulphate formation.

Kappen and Quensell concluded from investigations that the sulphur. released through putrefaction and the adion of bacteria on organic matter. and ang in the elemental form, is changed to sulphates. All the sulphur of organic matter and sulphides mast first be changed to the elemental form. The finely divided sulphur is so easily oxidized that the intermediate steps are not notloed. They also found that the form of sulphur affects the rapidity of change but that tho change was qaicker in soil than in air and in natural soil than in sterillzed soll. All the action is not attributed to microorganisms becanse sterilizing the soll may also destroy a certain chemical action. They found that In all solls the change to sulphates took place so quiokly that the sulphites or sulphides formed exercised no infurious effect on germinstion or futuro Erowth of the plant. $(i 2)$

Brioux and Guerbet proved the bacterial nature of aulphur 
oxidation in the 80 ll and shomed the infliencas of vartus substances on it. Tha rditition of crlcium sarbnnate grantiy accelerated oxidation, but sterilization of the soll almost entirely prevonted it.

Iossovich says the sulphur oycle is rather complinated, boing rade up of a change from organic to inoreanic form and $\nabla i c a$ versa, arie oxidation and reduction princtpalis through the setivity of microorganisms.

Demolcn studied the rate of transforration of sulphur in soil by adiing 5 grams of sulrhur to 100 grma portions of soil. He found that the sulphur aas partially oxicined to sulphuric acid. He also found that the reuction was most rapid in ron-storilized soil.

(25)

Lint. In his rork on the effect of the addition of froc sulphur on soil weidty. found that sulphur incronsed the liren requirement of the sail considerably. This, he cuncluded, tas due to the oxidution of the aulphur to sulphuric acid, since aftor the sevanth ตgok tho lime requirement remained tho same jrobably because all the suiphui had been oridized. (25)

Lipwas has demonstrated the prodiction of sulfhuric acid by mixing eleneutel sulphur and insoluble tri-calcium phosphate in compost heaps. Fie found that the insoluble plooshate was rendorod partly soluble by 1ta basos taking up the acld forted.

Shodd found by determining tho sulphate sulphur present before and after incubatiug 8011 vith elomental 3 ulphur, that about $60 \%$ Wras oxldized in four months. This was true thother 100 or 500 pounds per acro had been added. He wlso found that oxidation ia nore rapid in fine soil than in sand. The or Eunic sulphur in manurc alonf $*: 3$ Elo:ly oxidized. In the case of both soll and manire the aldition of calcium carbonate did not seom to increaso 
the oxidation.

Brom arid Kelloge bave made an extensive study of the produotion of sulphateg in the soll by bacteria and the effect of verinus gubatanceg on this procesw. Thoy state that thero aro numstous organiams in the soil winich cause snifofication, and these are grouped under the rame of sulfofying bacteria. Tho sulphur cyole in the soil is explained as boing made dp of several strges. First, organio compounde are broken dom with the production of hycrogen sulphide whioh is changed to free sulphur deposited as granules in tho oells of the bacteria. Inis free sulphur is oxidized to sulphates in whioh form it is avallable to plent8. Lurine the process of the rork it wes found that somo oxidation of sulphur to sulphates in the soil takes glace as a puroly chemical action independent of hacteria. This mas disoovered throuph an increaso in sulpinatas presant after shajing samples of solls with sulphides added in water for seven houro.

The method usod for datermiring sulfoficution in a ofls was as follong : 100 gram samples of fresis suil pore pleced in tumblers. 0.I grams of various sulphur matiorials addsa and this incubated fivo dnge at room temperatura. The sulphates prosent before and after incubation nore determized by shaxing smaples of the air-dry onls aith trics their veitht of water in bottios for seven hours and determinine the sulphates by pracipitating with $\mathrm{VaCl}_{2}$ and using the salphur photometor.

The conolusions rosched were that sodium sulphide and freo sulphur are the best forms of sulphur to uso for determining sulfofloation. The sulfofying powa: of solls was found to viry with different treatments. The use of stook manure or greon manure on solls inoreasod their nroduction of sulphates and in goneral it appeared that solls poor in organic matter vero lo: in 
sulfofioation.

The optimur moisture condition for sulfofication was found to be 50\% of saturation. This is also the best condition for plent growth, which may correlate optimum sulphate production and plant froisth.

Increased a e ration up to a rolxture of $50 \%$ fine soll and $50 \%$ and alwo increased gulfofioation. With hipher percents of sand sulfofication decreased whioh may have boen due to 3 lack of organic matter.

The effect of the addition of carboliydrates mas found to be detrimental in direct proportion to the amounts addod. Also tho detrimental offect varied in the inverse ratio to the solnoility of the oarbohydrate material.

In order to correlate sulphate production with crop erowth. greenhouse tests were carried out in pots of soil sown to timuthj. Thirty pounds of sol1 were veighed ont in exch pot and kept at the optimam moisture content of 50\% saturation. One series of duplicate pote ver kcpr hare ane hecterinlogicsil teste made from thom. while tho other serles was soeded to tirjothy.

The treatments rere as follons :

1. Nothing.

2. 25 T. horse manuro per acre.

3. $25 \mathrm{~m}$. con mare per acre.

4. 4. clover hay por acre.

5. 골 T. Cas per acre.

6. $\frac{1}{2} \mathrm{r} \cdot \mathrm{CaSO}_{4}$ por acre.

The sulphates present wore determined at 1rregular intervals by the mothod described above and sulforication tests mere also carrier out; an descrihed above.

From the rosults it was found that the aprlioation of calcium 
sulfide, cor manure, horse canure and clover hag to the soll inoreased to a considerahle extent the sulphate content of the soil. This increrse was greatest in the case of the meterial containing the largest amount of sulphur. This shows that the sulphur in insoluble. unavallable form in the soll 1 changed quite readily to sulphatos. Tho sulrhide was oxidized very quickly and the other materials only alightly less rapialy. Thus, under optimum molsture and temporature conditions in a fairly fertilo soil sulfofication undoubtedlJ ocours very readil.

A1so, the presence of sulphates in the soil was found to increase to a large extent the sulfofying porer of the soll. The greater the amount of sulphate the prester was the sulfofication up to a certain limit which wos not datermized.

The results of the crop yields indicate that the cow and horse manuro traatments gave the largest inorease over the chock pots. the clover and caleium sulphate a slightly smallor increase and the calcium anlphide no inurease. the calcium sulphide was rapidly osicizoa to sulphate and mowe sulphate was formed than was appligd in the sulphate treatment. This larger anoust of eulphate mut havo caused the smallar plelds than those obrained by the sulphate trestrent.

It is uhwn that both ranures and oalcium gulphate in small amounta had the same effect on crop jield and on sulforication. The offects of calcium sulphate on cxop ield and sulfofication are the same up to e certain amount of sulphate, bojond which the crop is not affocted byt sulfofioatior. is stil1 inoreased. This reviev of investigations on the changes which sulphur undergoes in the soll quite atrongly establisines the faot that insolub?e forms of sulphur are converted to soluble sulphates in the sell and that this action 1 m mostig bacterial. The silphates 
then are the source of sulphur for plant food.

As long as the total sulphur content of a soll is sufficient1y large to supply sulphur compounde for bacteria to work apon under good physical conditions of the soll there will probably be sufficient sulphates furnished to the plant. In this $w$ eg the tctal sulphur content of the soll is aiminished. This decrease has been shom from 8011 anoiyses already given. The remed. then, may be to furnish sufficient sulphur bearine materials to the soll for the bacteria to sork upon and thus prevent an exhaustion of the supply.

\section{Effect of Sulrhur on Plant Ürowth.}

The renl value to the plant of any form of fertilizer must be determined by growing the plant in soll with applications of the fertilizer in question. Numerous experinents of this nature have beon carried out with gulphur fertilizers. The results have been somewhat conflicting as a brief review of the moro important experiments, conducted especially for this purpose. will show. (27)

Hart and Tottinghan grew various orops in boxes of 33 pounas of soil under rreanhouse condtions. The fortilizer applications were hoavy, as follows :

Control (nc fertilizer).

Complete fertilizer. 26.5 grams.

Complete fertilizer, 26.5 prems $+\mathrm{Na}_{2} \mathrm{SO}_{4}$ 12. grams, Complete fertilizer, 26.5 grams $+\mathrm{CaSO}_{4}$ 12 grams. $\mathrm{Ha}_{2} \mathrm{SO}_{4}$ 12 Erans, $\mathrm{CeSO}_{4}$ 12 grams. sulphur(flowers) 5 grams.

The results were as follows :

sulpinur alone produced a decrease in growth and yield of 
beans, clover, pea seod, radiahes, rape, oats and barley. The oulphates increased the jiold of clover, pea sead, radisher. rape and barley and ost seed. None of the sulphates affected the erowth of oot and barley straw. Caloium eulphate prodnced a decresse in beans.

An analgeis of clover tops and rape from with the rarlous treatmonts showed that the sulphur content is increased by the presence of sulphates in the soll. It is known, however, that the sulphur content of soed varies littlo.

The above results indicate that plant members of the cruciferae and Leguminosae which contein large anounts of sulphur are affected most by sulphur fert1lizers. Tho gramineae show no increase in stram though seed production is markedly inoreased. In this oxporiment certain results may be due to other factors than plant food, oince very hoavy applications of fertilizer were used and the effect of different anounts of sulphates were not tried out. The deleterious offect of snlphur alone may have been due to the large amonnt applied or to poor soll conditions for 1 ts rapid oxidation to sulphates.

Ames and Boltz found, from pot and plot tests, that, in general. fertilizers containing sulphates gave higher crop ylelds of soy beans and rape than 8 imilar fertilizers not containing sulphates. The sulphur content of these orops mas also increased. uillet hny and seod gave opposite results from the above two crops as to jield, but the suiphur content of the hay ras increased, and that of the seod decreased.

Shodd conducter some pot exporiments with different form and arounts of sulphur and grew sereral kinds of crops. The inIuence of the sulphur fortilizers on the growth of the crop was 
determined and, in some casers, also the effect on the gulphur content of the plant.

In all cases poor results jexe obtained uriless the sulphur was edded to a rich $50 i 1$ or along vith a complete fortilizor.

Tobacco was inoreased in yield $24, \overline{3}$ by the use of 500 pounds of sulphur per aore or of 536 pounds of $\mathrm{CaSO}_{4}$ por acro.

Soybeans were increased in jield and sulphur content by the use of vartous forms of sulphates.

The gield of clover was not influenced by and form of sulphur due probably to the high sulphur content of the soil used. Similarly, the yield of turnips ras not affected.

Caobage was docroased rather than increased in yield by the use of large and small araounts of vexious forne of sulpliur.

Wuatard and radishes following tho cabbge ohowed frains from some of the sulphates. They mere espeoially benefioial in the case of mustard, and all showed an increase in yield over their corresyonding oarbonstos.

Alfalfa grown in sand cultures gave good increases from the use of elementel sulphur, and in rive out of fiftoen oases, the sulphates used gave better jields than their corresponding carbonates.

F. L. Duley in some sanc and soil cultares found that flovers of sulphur partly took the place of a soluble sulphrte in a nutrient solution when used in a sand medium, end had a marked effect on the production of chlorophyll in corn planto. In soll cultures flowers of sulphux used alone was slightly bonefioial to the growth of corn and rape and still more beneficial to the jleld of red clover. The preduction of nodules on the roots of the clover Eas very markejly inorgased. 
Reimer in one publication shors evidence of a beneficiel effect of sulphur on alfalfa production and in a lator publication Gires conolusive evidence from data of large increases of alfs.lfa from applications of sulphur fertilizers.

The results given in the second publication are as follows : Alfalfa 708 grom on plots recoiving varying amounts of eround phosphate rock, flovers of sulphur, iron aulphate and superphosphate. The ground phosphate rook plots gave no increaso over the check plote. The othor plots pith treatment of 300 pounds per acro gave an increase of slightly moro than $100 \%$ ovor the check plots.

Other plots were treated $n$ ith superphosphate, tron sulphate. florgers of sulphur. grpaum, Eround phosphate rock, wono-calcic phosphate, and steamed bone morl. Alfalfr, red clover and vetch Fore grom. The mono-calcio phosphate, Eround phosphato rock and steamed bone meal plots produced no increase in yield. The other treatmonts at the rate of: 300 pounds per acro all gavo inoreRsas, sore as high as $200 \%$ - 500\% over the chcck plot yieldz.

An analgsis of the soil tends to throw some light on the resalts obtained in the above experiments.

Lbs. per acre ft. of soll.

So11 Type

LFedord fine sandy loam T010 108m Medford clag loam (fatile soli)
Phosphorus

3357

23.34

3747
Sulphur

882

On the last soll applications of superphosphate produced no increase in yield. All the soj.ls are rich in phosphorus so that is not a limiting factor. But where sulphur is deficient the crop wes ahcra to be benefited by aprlications of sulphur fertil1zers. 
On the same soll types observetions of the effect of lime oulphir aprey on alfalfa, red elovor, vetch and caneda field peas under sprajed fruit trees showed larger, healthier and darker gxeen growth under the trees whore the 8 pray drippings had fallen than on the outside. This ras rat due to the lime because the soll was naturally rich in lire. The sulfhur in the spray may have been the cause of the better gromth.

The renults of four jears of plot experiments at the New (3i) Jersey station, using forrous sulphate and Eypsum, show no definite effects on plant growth unloss a stimulating effect. The authors state that any increase in yield with excessive applications of sulphur materials are due to its stimulating action and not to its value as a plant food.

The sulphate of iron, 100 pounds por acre, gave the largest increases in ary matter and total nitrogon of crops, but 200 pounds psr acre gave the least increase. Gypsum applled at the rate of 1000 pounds per acre eare an increase with one corn crop. The othor crops showed no appreciablo gain. (32)

Pitz glves the following results on the effect of elemental sulphur and $\mathrm{CaSO}_{4}$ on certain of the higher and lomer forms of plent 11fo. Testio mere mado in agar medium and in soil. Calcium sulphate hus a more benefiolal effect on bacterial and plant erowth than elemental sulphur. Calcium anlphate, 0.01\% and up. does not increase the number of incteria on agar plates but does increase the growth of logume bacteria. Amounts up to $0.05 \%$ increase yield and root eronth of clover.

$0.01 \%$ elemental sulphur and above increased hut gliphtiy the yield of clover and root fronth and nodule formation. It incressec ammonification but decreased nitrification and the total number of soil organisms. 
Brom and Johnscr. in their studies on sulferication usca soil which was tco rich in sulphur to drem any conclusions as to the effect of applications of sulphur on plant Erovth. It contained per $2,000,000$ pounds surfece soil, 911 pounds of phosphorus and 2487 pounds of sulphur.

They found that the sulfofying power of the soil wa inoreased by applications of caloium sulphate, mono-calclum phosphate. acid phosphate, rosk phosphate and rock phosphate plus calcium sulphate. The sulphate and phosphate alono had greater effects than combinations as in acid phosphate. All the treatments increased the ammonifying power of the soli to practically the samo extent.

Tho orop yield\%, gufofication and armonification rosults did not always run parallel. Acid phosphate gavo tho Ereatost increaso in the orop of oats, probably aue to lack of phosphoric acid in the aoll and its ready arailability in the acid phosphate. (34)

Pfeiffer and Blancle conclude from their experimente that sulphur does not benefit plant erowth nor increase nitrogen availability in the soil. It seems to produos a very emall harmful effeot in some cases. A oertain benoficiel effoct is duo to the action of sulphur on fungous direrses.

(35)

Pfelffer and simmormacher conductod exporiments on tre action of sulphur in plant nutrition. They conclude from their reaults that sulphur fertilization is wholly ineffectivo on tho soils used and that a recommendation for the general use of sulphur is not justified.

(36)

E. B. Fred worked on the possibility of carbon bisulphide furnishing sulphur as a plant food. Hs found that the aldition of carbon bisuliphide to the solit produced a temporary reduction in the number of mioro-organisms and then a decided inorease. 
This was due to the disinfecting aotion. Tre acount of soluble compounds of nitrogon and sulphur were increcsed.

Tho action ou plant orowth varied with different soils and different crops. Using a loam g011, backwheat, oats and mustard were most bensfled. The grouth of red clover in peat soil was increased. The jield of mustard was increased in all experiments in non-acid solls, showing sulphur to be most beneficial there. (I2)

Dymond. Hughes and Jupo report both plot and pot experiments जith salphur fertiliners. In plot experiments comparing muriate and sulphate of amonia the jield of cabbage and clover was increased by tho sulphato Fhilo that of oats, barley and swode was not benefites.

Analysos of the crops showed that under favorable oonditions the presence of gulphates increased the albuminoid content as well as the total relight of the cron, showing that the eulphate has a direct offest on the plarit. This was true of vetch and maize Bromn.

The conclusion wag made that the supply of sulphur already in the soil or brought down in the rain is not sufficient for heary yielding crops rich in albuminolds, gither for the production of greatest yield or the highest feoding value, and for such orops a sulphate should be included in the artificial manure. For cereal crops and for perranaent pesture the soll and rain provide all the sulphuric aold necessury.

In some cases effects have been noted from the application of sulphar for other purposes than as a fertilizer. Such hins been the case in applying salphur to potatoes for scab prevention. (37)

sherbakoff found that in general the application of about 100 pounds sulphur. por acre somethat increased the jield, but 300 pounds and over materially decreased tho yleld. Applications of 
11 me decreased the injurioue after effect of large applications of sulphur for scab.

No definite results were obtained as to the fertilizing value of sulphur on rotatoes.

Wheeler. Eartwell and dioore grew crops in pots of soils from the treated plots. They found the jield of oats and millet less where sulphur had been used for potato scab. The decreased Jield was not so gxeat whore lime was usod.

In both the above experiments the infurious after-effects were probably due to the acidity caused by the oxidation of large amounts of sulphar. This mas partly corrected by applications of lime. An excess of gulphates was undoubtedly present so that no difference in plant growth conld be noted if the acidity had not been deleterious.

AlI important evidence oncerning the direct of foct of gulphur on plant nutrition mast be obtained from experiments plannod egpecially for that purpose. The long standing field fertilizer experiments at college stations ond in other countries were planned for determining the effect on crops of the three essential plant food elements only. However, there is some evidence which may be said to poitt toward the favorable influence of sulphur on crop growth.

In some Rhode Island station experiments the double superphosphate Eives somewhat poorer results than three acldulated phosphates. This, Hopkins states, is probahlj due to the stimulating action of the large enounts of oalcium sulphate in the acid phosphate. In this case that must be true since sufficient sulphur for plant growth is applied to all plots in the uniform trostment of 398 pounds of potassium sulphate per acre.

A comparison of Eround bone and dissolved bone black as a 
fortilizer in some Pennsylvania station experiments seems to give no eridence for the beneficial action of sulphur fertilizers. thougli this moy be due to other stronger fretors.

In some fire and three jear rotation experiments at the onlo (41) Station the following results are shown :

F17e joar rotation. Av. jlolds por A., bu. and Ibs.

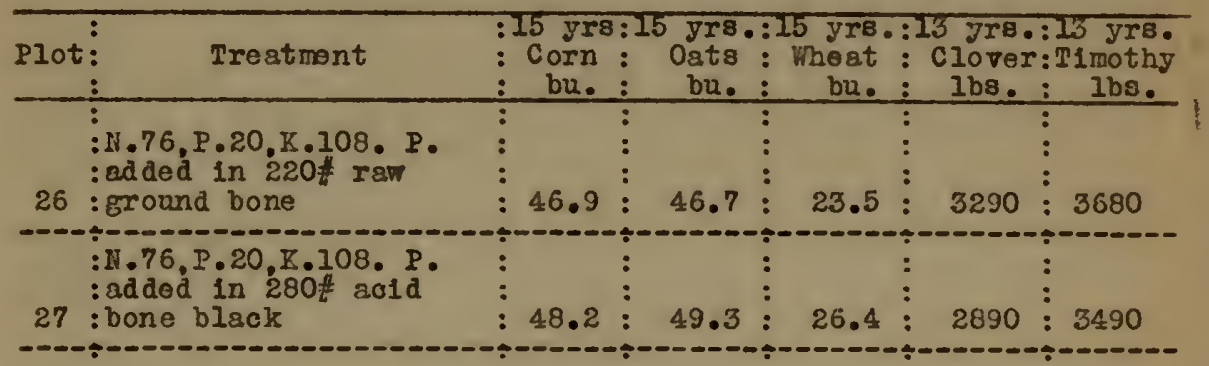

Three year rotation.

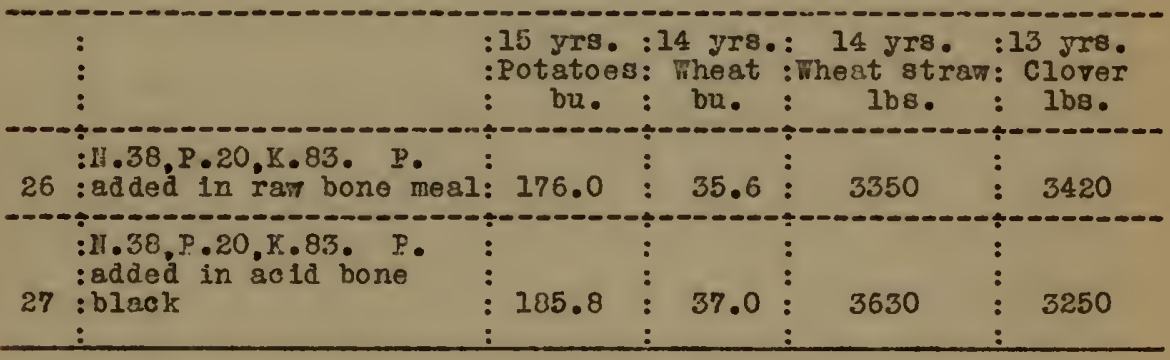

The acid bone black gives larger average yields than the bone without the sulphuric ac1d.

A comparison of alfalfa ylelds on sulphate of potash and fur(43) late of potash plots at the Mrssachusetts station show yields markedly in faror of the eulphate plots. This agrees with results (30) shown previously though in this case the sulphur content of the soll is not knom. Also, the alfalfa seen groming presonted a vigorous gxeen healthy appearance on the sulphate plots and a woaker jellowish appearance on the no-sulphate plots. 
1/8 acro plots. Fert1lizer treatient.

For 21 Jenrs, 600 pounds fine ground bone anmally. Ho manure. In 1910, 2 tons 11 me per acre.

Ince 1900, 250 pounda per aere annually of $\mathrm{zCl}$ or $\mathrm{K}_{2} \mathrm{SO}_{4}$.

Two year averege gields.

Tons per acre.

\begin{tabular}{|c|c|c|}
\hline & : $x$ plots & $\mathrm{x}_{2} \mathrm{SO}_{4} \mathrm{plot}$ \\
\hline Grim AIfalla & $: 5.734$ & $: 4.231$ \\
\hline Common Alfalfa & 2.886 & 3.636 \\
\hline
\end{tabular}

* Manurial treatment.

Alfalfo gielda.

Tons per acre.

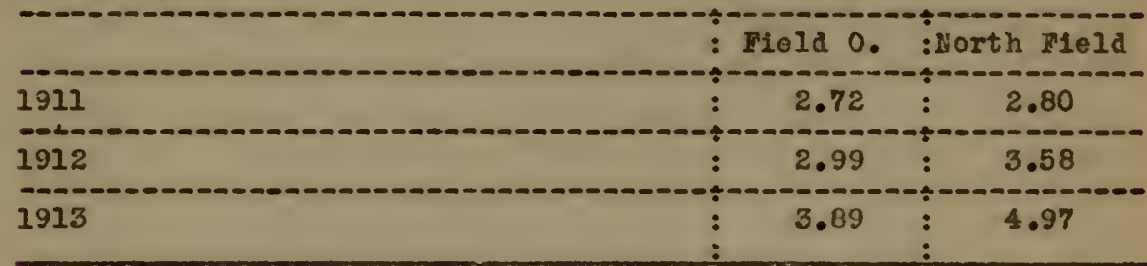

* F1old D. 1910-1912 Inclusive, Bone mesl, 600 lbs.

KCI 2001 bs.

1913, Basic alag meal, $10001 \mathrm{bs}$. Hot proviously manured JCI 200 lbs.

North Field. 1912-1913, Basic slag mol, 1000 1b8. Previously manured anmualig.

Experiments such the above do not show conclusive results regarding the value of anlphar as they were not planned for that purpose. Many unoontrolled factors exist, such as tho indirect effects of afferent naterials and differant solubilitiee of different forms of plant food. But at least somo experiments, auch as the last given, show such definite results in one direction that the influence of the sulphate fertilizer seems probable. 


\section{Direct and Indirect Effect of Sulohar on Plant Grorth.}

With any material added to the soll to benelit plant growth there is a possibility of a direct or indirect benefit unlesa one action only has been proven to be important. On this point there are conflicting opinions in the case of sulphur fertilizers. (44)

Hopkins states that calcium sulphate acts as a crop stimulant but supplies no plant food of value.

Ilobig states that in Franoe sulphuric acid hes been poured apon the flelds after the removal of erops and has beon found to form a good manare. This he aseribes to the formation of eypoum in the so11. Gypsum, he states, servos a tmo-fold tunction : Plrst. that of decomposing oarbonate of ammunia sund of fixing the ammonia. which uay bo performod by other salts of calcium: and second, It acts as a sulphate which cannot bo supplied by any alt of lim not containing sulphuric acid.

In regard to one possible indirect effect of elemental sul(25) phur applied to the 8011 . Iipman shows experimentally that 1ts oxidation to sulphate 111 not maixe insoluble phosphates soluble unlese in a more concentrated mixture than can be made in the soll. $(46)$

Hopkins has atated that the high sulphur content of plants does not represent their needs but denotes the presence of an abundance of sulphates in the so11. This statement 18 s so true of phosphates when an abundant supply is present in the so11. It is probably the case Fith sulphates in the sters and leares of plants but not in the soed. which hss been shown by Peterson to maintain a fairly constant percontage of sulphur. (47)

Fred and Hart have shown a much more beneflolal effeot of phosphates than of sulphates on 8011 baoteria. Sulphates, thereforo. do not funotion indirectiy in this way as much as phosphates. 
The character of tho compounds in alfferont planto shor a varying demand for sulphur. For the manufioturo of soms of these organic compounds, such as the albuminoids. large amounts of sulphur must bo used directiy by the plant. Th18 18 shown by the wido alfferense in sulphur content of the cruciforous plants and the cereal plants.

Thur, the aulphates in the soll mist have a drect food relation to the plent, and oonsidering the amounts removed by gom plants and the decressed sulphur content shown in somo so11s. 1t would seem that anlphur may become sa alrect a limitine fnctor in orop production ae nitrogen, phosphorus or potesh.

Namerous other investigutions on sulphur fertilization besides those already mentioned have been publishod. The followinf abotracto are from exticles to which previous referenoes havo not been made.

Demelon found that sulphur was oxidized to sulphate in tho so11. He obtained an incrensed yleld from flowers of aulphur. (10 grams per square meter of soli) applied to miabrgas, baets and parsnips.

(4.9)

Later the sine man found that potatoes pare benefited the most by epplications of aulphur but that the adtion diminished when large amount of organic matter and minerel fertilizers were added at the same time.

P. Grannetto obtained an increased yleld of potatoes from sulphur applied at the rate of 400 pounds per acre with other fert1l1zors. When applied alone a decrense in Jiold was obtained. (51)

Takouchl found that gypoum decreased orop Jleld when used with aold fert1lizers but increased it when used with alkalin fert111zers. 
T. Junloaud from some pot experimonts with tomato plants showed that 2 grams of sulphur alone per kilograrn of soil had a deleterious effect on growth. When used pith aminonium sulphate or a complote fertilizer a benefiolal offect was secured. (53)

E. Rabate found that a sulphurio aold solution, when appliod for the destruotion of woods in a whoat fleld, had a fertilizing action on tho 8011 .

Chansrin and Doersot used sulphur at the rete of about 223 to 146 pouncs per aore with superphosphate, potasiın su?phate and sodium nitrato on potetoes and beets. The ylelds were increased and disoaso reducod. $(\dot{5} 5)$

In anothor work these men found that 178 to 350 pounde of sulphur per aore gave inoreases in ylelds of potatoes and beots. (56)

B. Heinze cunclucied from exporiments that the action of sulphur is sirilar to that of carbon blaulphide but is not entirely biologioal and is not rell mnderatood.

V. V. Sabaskniko obtained a better growth of barley and ryo from the applioation of 10 grams of sulphur per aquare motor of so11.

E. Borllanger arded 70 grang of sulphux to 30 inlograms of 8011. The influence of the sulphur was favorable to the erowth of carrots, boans, colory, lottuoe, sorrel, ondive, potatoes, onions and spinach in natural so11 but not in sterile so11. (59)

I. Bouj.lengor and s. Dugardin consluded that the favorablo influence of small doser of sulphur was due to an aotivating oflect on ammifying and nitrifying bateria. $(60)$

Da1kuhara found from pot exporiments with three volls that oven less than $0.02 \%$ oulphur trioxide in the soll was sufflolent to meot the requirements of barley plants for sulphux. (6I)

Bemhard claims that sulphur disinfects the so1l, pate it in a 
better phyeical oondition, oauses a quioker and moro intensive action of the commercial fectllizers applied, nakes more avallable the foodstuffs already present in the soll and plays a greator role in plant nourishment than has hitherto been ascribed to 1 . (62)

Bornhard later applied sulphur at the rate of 44 pounds per plot of 600 square jards and obtained a beneficial effect on hoed crops, potatoes and mangolds. (63)

Magnien shows that sulphur at the rate of 2-3 grains per square meter placed in the rows at plarting time apparently doubled the yields of turnips and beets. (64)

Iritsohler found that oulphur inoreased the field and sugar content of mangel wurzels.

\section{$(65)$}

H. von Follitzen found that out of five varieties of potatoes all but one yielded more on plote receiving 356 pounds of sulphur per acre in addition to normal fertilizers tian on plots receiving no suiphur.

Suchting shovs that ammonium sulphate increased the gield of potatoes more than did sodium nitrate. $(67)$

Carlier demonstrated that manganese sulphate does not have (68)

a high manuriel value. He also demonstrated that the high opinIon of the fertilizer value of magnesium sulphate was unwarranted. (69)

D. Zolla found that the fortilizing action of sulphur on vines was increased when mixed with organic matter and used in large amounts.

(70)

Haizeres found that 250-500 kilograms of sulphur per hectare Increased the ylelds of potatoes and beets. (7I)

Herlinger reported higher glelde of potatoes in eulphured rowa.

F. Gianitto found that sulphur alone at the rate of 400 pounds per acro Gocrosied the jield of potatoes, but when combined with 
other fort1lizara.1t lncroased the glold.

(73)

Llerke observed that fert1Iizera contalnlags eulphates gave better results than other fortilizers with Pmits. (74)

Joset Urban forad that sulphar ased st the rate of 178 pounds por aore vith amonlum gnlphsto and chlll salipoter slizhtly inoreand the j19ld of sugar beote. $(75)$

ㄱ. Thelin roports acpe experimerta gith alfferent formo of gulphar. Wost Fero oxiained to sulghates in the soll. (70)

14. Corcolet obtained increased ylolds of beans, poas, onions. potatoos and soparagus from applicationo of eulphr. (77)

Changit fowa silphur to have a farozuble influenos on the slold of Grapes, espocialy when aprllac with fortilizors hich in organic matter.

(7e)

Liecht 1 found fron experiments that an inerouse of eulphur In fertilizars and ands torde to frodnce an increase in the amount in orors.

Termorel and Dantony found oreanic sattor to bo injertant in obtainlne boneflofal results from applicatlons of sulpiux. $(80)$

DesruIi obtainga large Incrases in Jioldg of booto and tur-

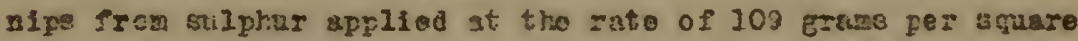
mater. He conoluad that this migint bo due to the nalniates forrea or to a sireot st Imaratirip notion of salphnr on the plant. 


\section{Losses of Sulphur from the soll.}

A consideration of the sources and anount of 108 s of eulphar from the soll is important in determining how mach effort wat be made to offeet this 108 s and maintain an adoquate supply for plant growth.

There are two sources of 108s, namely, drainage and cropping. The nature of oulphur compounds in the soll is ouch that $108 \mathrm{~g}$ by arainage 18 coneiderable. The sulphates formod in the so11, 11k0 nitrates, are readily loached out. For this reason, there may be no accumalation of a supply but those not used by the plant are leached out and more must bo formed from insoluble sulphur compounds. Accordingly. the addition of emil amounts of sulphates In fortilizers will not permentntly inorease the anount in tho (82)

so11. Work done by Professor Morse of the Yssachasetts Experimont station shows just as wach los of celcium from the soll in the form of a sulphate as in the form of a chloride. This was dotormined by soll analysis from plots treated with mariate and sulphate of potash for twenty-two jears. Though calcinm chloride is known to be more soluble than calcium sulphate, he shows by 11greses that the average annual rainfall for a buald region 18 more than sufficient to dissolve out all the calciun sulphate formed from an ordinary application of potasaium sulphate. (83)

Ijon and Bizsell show that the 1088 of oulphates in drainage water varies considerably with the soll treatment and cropping. Their results from 1 ysimeter tost are as follows : 


\begin{tabular}{|c|c|}
\hline Treatme nt & $\begin{array}{l}\text { I0s of oulphates per } \\
\text { ! sere ennually }\end{array}$ \\
\hline $\begin{array}{l}\text { Hariure, l1ght application, no } 11 \text { me, } \\
\text { uncropped. }\end{array}$ & $44 \quad 1 \mathrm{bs}$ \\
\hline $\begin{array}{l}\text { Manuro, light application, no limo, } \\
\text { cropped. }\end{array}$ & $31.81 \mathrm{bs}$. \\
\hline $\begin{array}{l}\text { Manure, 11ght application, 11mo, } \\
\text { uncroppod. }\end{array}$ & $53.12 \mathrm{bs}$. \\
\hline $\begin{array}{l}\text { Sulphate of potash, } 200 \text { lbs. per acre, } \\
\text { no Iime, cropped. }\end{array}$ & 56.4 1bs. \\
\hline $\begin{array}{l}\text { Sulphate of potesh, } 200 \mathrm{lbs} \text {, por acre. } \\
\text { lime, cropped. }\end{array}$ & $62.01 \mathrm{bs}$ \\
\hline
\end{tabular}

It may be seen that the addition of I1me incresses the 1088 . probably due to the ready formation of calcium sulphate. An application of a sulphur carrying fortilizer also incroases the 1088. Hore gulphates ero lost when no crop is present than when one 1 prosent with $81 \mathrm{~m} 1 \mathrm{lar}$ treatment.

Faprecht and Norse have shom a Eroater 1088 of sulphur in the arainage wator from plots treated with ammonium sulphate than from plots treated otherwise. (85)

Eall gives I1gures on the loss of sulphur in arainage water. Ho states that 50 pounds of sulphar trioxide 18 lost annually per acre Irom unfertilized Rothamsted plots and 85 to 220 pounds annuliy per acre from fort111zod ploti.

Dymond, Hughes and Jupe g1ve the loss of sulphar trioxide in arainage water Irom Barn $7101 d$. Rothamated as 71.4 pounda per acro anmusily, a loss to the 8011 of .001\%.

That sulphates are not as stable compounds in the 8011 as phosphates is seon from any complote analysis of drainage waters. Sulphates have been compared with phosphates as possibly becoming of equal importance in soil fertilization. The large amount of 
sulphur lost in drainage paters seoms to indleato that the soll supply may become exhapeted quicker than in the case of phosphorus. This is seon in the compliation of drainage water analyses from somo Rothanstod plota as given by llall.

Analyses were made of the drainoge water from varlous plote with different trestmente.

\begin{tabular}{|c|c|c|c|}
\hline & $\begin{array}{l}\text { :Parta p } \\
\text { :Harimum }\end{array}$ & & $\begin{array}{l}\text { mililon } \\
\text { inimure }\end{array}$ \\
\hline Phosphor10 ac1d & 1.66 & $:$ & 0.17 \\
\hline 3ulphuric ac1a & 99.70 & $:$ & 21.90 \\
\hline
\end{tabular}

Added to the 1088 of sulphrr from the 8011 by drainage 1 s the large amounts taken ap by crops. Whis is show in tho fullowing (14) tablo from shodd.

Pounds of sulphur and phosphorus removed per ecre by average crops.

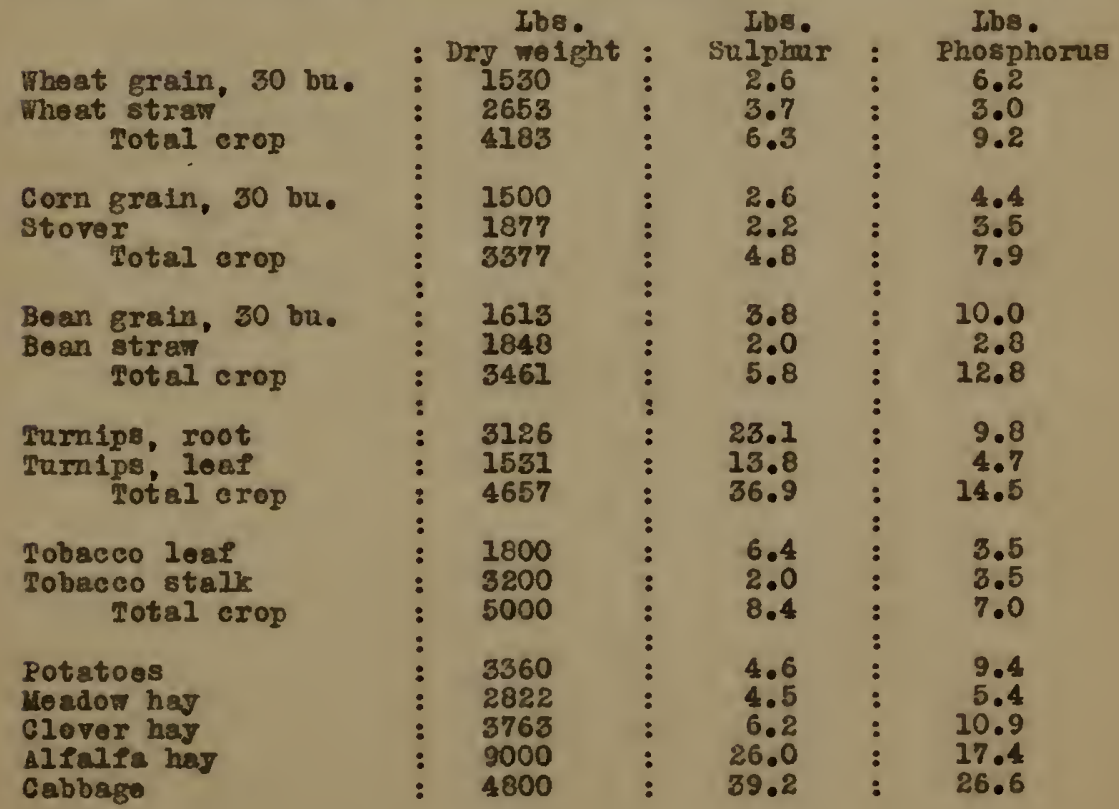


Sources of Sulphax supply to the soll.

To offBet the constant removal of salphux from the soll there are numerous sources of supply. It has been shown that virgin soil contains a fairly largo amount of eulphur. This probably camo crginally from mineral compounds such 28 pyrites and from docaged vegetation. Another natural supply of oulphur is the rainfell. There is considerable sulphur gas in the atmosphere, chiefly in the form of the trioxide. Tho amount varieg with the noarnegs to some source of sulphur gas such as decaging organic matter or burning coal. Thus, near torns and factories more sulphur trioxide is present to be washed from tho atrogphere than is found in the open country.

Tho amount of sulphur brought to the soll by rainfall has been determined by various lnvest 1gat ors. (23)

Kossorich found that the sulpher falling with the rain annuelly por acre variod from 9 pounde in the country to 72 pounds in the neighborhood of towns. He concluded that a cont inuous introduotion of sulphrr from the atmosphere is essential to vegetation and for maintaining apply to offeet the rapid depletion from the 8011 by loaching.

Dymond. Huges and Jupe found the annual rainfall to bring down 18.5 pounds oulphur per sore in the country, and 50 pounds per sere nesr torns.

(6)

Hart and Peterson quote Hall as showing the average annual precipitstion at Rothamstod to be $18 \frac{1}{2}$ pounds of $5 x$ phur trioxide. Thoy also give determinstion of sulphur trioxide in the rainfall noar Kadion, Wisconsin. For five months of the joar the reinfall was 11.14 inchos and 10.70 pounds of sulphur trioxide por acro were brought dow. Their figures are incomplete for a year 
but show that there is a monthly and probably a seasonal variation in the amount of enlphar trioxide furnished the soll by rainfall.

It is undoubtediy a afe to conclude from the dats given that the annual 1088 by leaching mon more than offets the oupply of sulphar brought down by the rain, and sinoe this leaohes from the soil so rapidy. there is no accumalation from this source for the use of the plant. Therofore, to furnioh ar avallable supply of sulphur, some other means must be employed than the transitory arount $\mathrm{B}$ in the reinfall and the naturel supply in the soll which ज111 not raplen13h itself.

Stock manuros contain sulphur as moll as other plant food watorials. Inis is unioubtedy an important source of aulphur to the soli in regions where sufficint $1 \mathrm{~s}$ produced to be of value. As to the per cent of sulphur in different stook manures, no av- rage data has been obtalned. It 18 lonown from a study of phyalological ohemistry that a greatar arcount of aulphur is excroted from the body in the urine than in the undigestod solid matter. It gets into the urine from the oxidation of protein material in the body. Analyses of human urine give about $3.3 \%$ total sulphur. Th1s would probably be about the same for farm animals. Since - large proportion of the arine is apt to be lost, the per oent of gulphur in the manure pllo would be considersbly lesa than in the urine.

Brom and Kollogg state that 10 ton application of horse manure and cow manture retarn to the 801112.28 and 16.02 pounds of sulphur respectively. Aseming this to bo a ponoral average for manures, the amount of gulphur returned is seen to be small.

Besides stook manures there are numerous oomercial fertillzers used which contain sulfhur. The most comon of these with 
the average amounts of salphur carsiod are as follow: :

100 1bs. ac1d phosphato ............8 1bs. sulphar

100 1bs. armonium sulphato ............24 1bs. sulphur

100 1bs. potessiun sulphate ............18 1bs. sulphur.

Lainit contains oonsiderablo sulpiur. Basic slas a.so contalas some salphur. Organic fort1lizers such as dried blood. tankage, ote. contain varging anounts of alphur, mostig in organio combinstion. Sodium nitrate, potsssium chloride and calclam cyanamid probably contain no appreciable amount of sulphur.

Thus it 1 s geen that there are numerous sources of sulphur aupply commonly in use vithout considering the use of elemental sulphur alone.

\section{Maintainine the Sulphur Supoly.}

Different soctions of the country eupport alfferent types of Iarming. Within these types the method of fertilization rast be adapted to conditions. One system of fertilization, then, w111 not flt all types of farming. However, a broad question suoh as the sulphux supply may be worked out for a for closely related types of farming under similar soll and climatio conditions. Thus, 11 types of farming as found in Massachusetts or, more broadiy, in the NeV Eagland Statos, may bo considered as similar1y affecting the above question. This rould not inciude types under different conditions cf 3011 as found in the Idale West. The chief farming practises in hasuchusetts may be olassod as dalrying, truck farming and intensivo tobacco, on on and potato raising.

Birst, we wi11 consider deiry farming. Can the sulphur supply of the soll be maintalnod alone by tho manure produced? According to Varren's "Farm Management". the Iarger stock on a farm 
w111 produce about one ton of manure per month per 1000 pounda 11.ve weight. For a 150 acre farm, then, with 15 cowe and 4 horsen about 21 tons of manurs might be prodnced per month. During four months of the jear, 15 tons of this might be lost frov the cows at pastare. This would leave an average yearly production of about 200 tons. The amount produced by other stock than cows and horses woula be negligible.

Supposing the ohlat crops raisod are 40 acres of hag. Including 20 of clover, 15 aeres of corn, 10 acres of other graina and I acre of potatoes. The rest of the land wieht bo pasture and wast land to whloh no mamure is applied. Thio would remove annually about 400 pounds of sulphur in crops wh1le the meximum amount of sulphur applied in 200 tons of mamare rould not oxceed 350 pounds, accrding to the for I1gures ware. Green manare orops and crop residues would roturn only what sulphur they had romoved.

Thus, from theoretioel figures, it is seen that the salphr supply cannot be maintained oren on dalry farms by stock marure alone.

In the othor two types of farming, little manure is producod. Considerable is parchased from cities whore possible but it is generally imposaible or toc expensive to purchase sufficiont to be used alone. What amounts are ased w111 not furnish sufficient sulphur for intensive cropping oter lone periods of time.

For all types of farming in Kassachusetti, largo amounta of commercial fertilizers must be and are used. This practioe over the state varies and the amounto used cannot bo sccurately atated. Director Brooks of the Kassachasetts Experiment station has recommendations which are followed to a certain extent throuchout the state. These recomendat10ns, as D1rector Brooks states, are 
designed to supply the optimum amounts of plant food so that the maximum returne may be secured for all labor expended on the crop. The anounts are probably aomewhat in excess of those commonly used by the farmere but, nevertheless, they indicate what the average practice through the etate mas be.

Some of these fertilizere though applied primarily to aupply other plant fooda contain generous amounts of sulphur. Some figures comparing the amounts of sulphur oupplied in this way with the amounte remored by the crop will ahow whether there 1 is $11 k e 1 \mathrm{~g}$ to be any necesaity of applying aulphur alone for maintaining fertility in Masaschuotta so11a.

\begin{tabular}{|c|c|c|c|c|c|c|}
\hline crop & $\begin{array}{l}\text { : Sulphne carryln } \\
\text { : fortilizerg re- } \\
\text { oommended } \\
\vdots \\
\end{array}$ & $\vdots$ & $\begin{array}{l}\text { acre } \\
\text { with } \\
\text { manure }\end{array}$ & $\begin{array}{l}\text { aulphur } \\
\text { : added } \\
\text { :per ecre } \\
:\end{array}$ & $\begin{array}{l}\text { : oulphuz } \\
\text { :removoc } \\
\text { :by acre } \\
\text { :of cror }\end{array}$ & $\begin{array}{l}\text { oxcoge } \\
: \text { : } 1 \text { phur } \\
\text { : over crop } \\
\text { :demands } \\
\text { : }\end{array}$ \\
\hline Corn & $\begin{array}{l}\text { :Acid phosphato } \\
\text { :Bes 10 slog* }\end{array}$ & $\vdots$ & $\begin{array}{l}400 \\
500\end{array}$ & $: 32$ & $: 4.8$ & 27.2 \\
\hline Hay & $\begin{array}{l}\text { Amnonium silpha } \\
\text { :Ac1d phosphato }\end{array}$ & : & $\begin{array}{l}100 \\
300\end{array}$ & $\begin{array}{l}24 \\
24\end{array}$ & 6.2 & 41.8 \\
\hline Onfong & $\begin{array}{l}\text { : Tanikago } \\
\text { : Badic slag } \\
\text { :Ac1d phoaphate } \\
\text { : Sulphate of } \\
\text { : potash* }\end{array}$ & $\begin{array}{l}\vdots \\
\vdots \\
\vdots\end{array}$ & $\begin{array}{r}200 \\
800 \\
1000 \\
250\end{array}$ & $\begin{array}{l}- \\
80\end{array}$ & $\begin{array}{l}: \\
\vdots \\
\vdots\end{array}$ & $: 101.2$ \\
\hline Potatoo & $\begin{array}{l}\text { :Am. aulphat } \\
\text { :Acid phosphate } \\
\text { : Sulphate of } \\
\text { : potash* }\end{array}$ & $:$ & $\begin{array}{r}80 \\
1200\end{array}$ & $\begin{array}{l}14 \\
96\end{array}$ & $\vdots$ & $:$ \\
\hline Tobacco & $\begin{array}{l}\text { :Cotton seed mea } \\
\text { :Am aulphate } \\
\text { :Ac1d phosphate }\end{array}$ & : & $\begin{array}{r}1700 \\
200 \\
500\end{array}$ & $\begin{array}{l}48 \\
40\end{array}$ & $:$ & 79.6 \\
\hline
\end{tabular}

The abore table ahowe a very large excess of sulphur over that used by the orop. In sotual practice mach of this would be leached out but undoubtedly more than the orop neods 18 retained in the ooil by adrorption. A more pernanent eupply is 
given to the soll in slowly decomposing organic matter from manures. All the preceding figures have been based on the asaumption that the 1088 of sulphur by leaching equals or exceeds the amount brought dow by rainfall.

Thus, under syatems of farming as found in Der England thoro Beoms to be little danger of oulphur's over beooming a liniting factor in orop production. Such may not be the case, however, in regions such as the Miade Fest where crops are produced extensively from the natural fertility of the soll or with the ald only of green mamrea, crop residues and limestone.

\section{Sulphar in Acid Phosphate.}

It has been pointed out that many commercial fertillzers commonly used for the purpose of supplying aitrogen, phosphorus or potassium also furnish considerable oulphur and that they thus ald in maintaining the sulphur aupply in the soll. Acld phosphate is one of the most oxtensively used of these sulphur carrying fertlizers. Its high officlenoy as a fortilizer has been demonatrated in comparison with other phosphorus manures and largely attributed to the ready avallabllity of 1 tg phosphoric ac1a. Jome have olaimed that the calcium salphato contained in It also aids by a stimulating sction on plant erowth. The questian also arises as to whother part of the beneflcial action of ac1d phorphate is not due to the use of the sulphur as a plant food.

The following work was planned to determine the effect, if any, of the alphur in acid phosphate on plant growth:

Kethod of Procedure.

Data, turnips and olover were grown for about three months in three-galion glazed earthon ware jars in the greonhouse. Ho drainage was allowed from the fars. Watering Irom the bottom was 
practiaed almost exclusively through a glass tube in the center of each jar as shown in the photograph. The optianm molsture content of the soll was determined and each pot was kopt up to this by frequent applications of tap water.

The oate were thinned to ten plante por pot, the tumips to Ifve and the clover to thirty-11ve. At the ond of the growing perlod the crops were harrested and oven-dried and these weights taken for the calculation of results.

The fortllizer treatmont per pot was as follows :

Pot Ho. :

Troatmont and amounts

:Nitrato of soda, 400 Ibs. per A. $(0.2264$ grams $)$.

0 :llarlate of potash, $300 \mathrm{Ibs}$. per A. $(0.17$ grams):

A : Same as abovo pIus double superphosphate, freo from

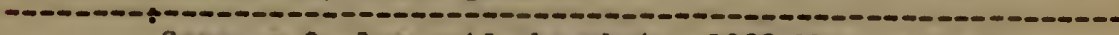
:Same as 0 plus acld phosphate, 1000 Iba. per A.

$B \quad:$

(0.566 grams)

c :Sarve as A plus sulphuric ac1a, 0.2009 grans.

D :Same as A plue Plowers of sulphar, 0.0656 grama.

E :Same as a plus calcium sulphate, 0.3528 gramo.

0

IO : Same as 0 plus 2000 Iba. I1me per A. (1.132 grams Ca(OH) 2 )

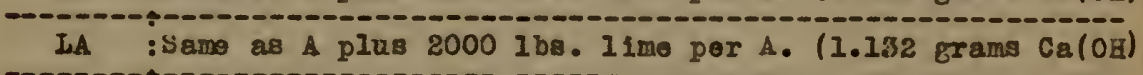

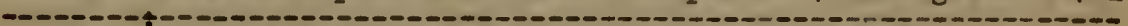

IB : Same $2 \mathrm{~s}$ B plus 2000 1bs. I1me per A. (1.132 grane $\left.\mathrm{Ca}(\mathrm{OH})_{2}\right)$

$-\ldots$

IC :Same as C plus 2000 Ibe. I1me per A. (1.132 gram Ca $\left.(\mathrm{OH})_{2}\right)$

ID : Same a. D plus 2000 Ibs. I1me per A. (1.132 Erams $\left.\mathrm{Cs}(\mathrm{OH})_{2}\right)$

LE : Sam as plus $2000 \mathrm{lbs}$. Iime por A. $\left(1.132 \mathrm{grams} \mathrm{Ca}(\mathrm{OH})_{2}\right)$

The object of the fertilizer treatment as given was to determine the effect on plant grouth of the sulphur contained in an application of 1000 pounds of acid phosphate per acre. This 18 done by comparing treatments of ac1d phosphate and other forms of sulphur. of the came amount as found in the acid phosphate, with 
treatments of a doublo superphosphate carrying an oquivalent amount of water and oitrate soluble phosphoric acid but no sulphur. Equal amounts of nitrogen and potash were added to each pot. The effect of 11 me was determined by adding oqual amounts of calcium hydrate to one duplioate set of each treatment. Duplicate pots were ueod in all cases.

The double superphosphate was made by troating finely ground rock phosphate with pare phosphorio acid. The Iine ground rook was found to contain a amall amount of sulphor. This was practically oliminated by oalring in oxggenated water and dooanting repeatedly. A trace of sulphur atill remained, probably in the mineral pyrites, bat the amount wag negligible.

A phosphate fas Iinally obtained which gave noarly the same per cent of water and citrate soluble phosphoric acid as the acid phosphato used. The amount of double euporphosphate for each treatment was then calculated so as to givo tho same total quantity of water and estrete soluble phosphoric aold as the amount of acid phosphate used ccntained.

To obtain similar sulphur treatronts the acid phosphate was analyzed and found to contain $29 \%$ sulphur trioxide. The same emout of sulphur was sảces in the form of sulphuric acid. Ilowers of sulphur and calolum sulphate as was added in the acid phosphate.

The soil used was obtainad from an experimeatal plot on which crops had bean grown, but no fertilizer applied, for the last twontysix years. It thus representa an average fine eandy loam boll of very 10 fertility. Th1s wa partially air drlod and thon sifted to get rid of all large pebbles and forelga material. After beIng well mized to insure unifo rmity in the pot. 11881 grame was added to each jar.

The fert1lizers were well mixed with the npper half portion of 
the soll in each pot before 1t was poured in. The sulphuric acid was added in dilute solution to the top of the soll just before the seeds were sown.

An anslysis of the soll for total calphar by the sodiun peroxide Insion method as outilnea by Hart and Petergon gave $0.05 \%$ sulphur trioxide. An adjolning soll which had grom the same crops but had recelvad an annal application of a complete fort1lizer. Including disolved bone black as a alphur carrier. was found to contain $0.059 \%$ sulphar trioxide. This conflrme the (6)

work of Hert and Feterion and others showing a decrease in total sulphur content of the sol1 due to cropping and lack of fertilizat ion.

ReanItr obtained.

The results as shown by the growth of each crop were es folIows :

Series 1. Oats.

(Seed gown January 26th. Crop harvested lay 11th.)

When harvested the grain was not mature but the heads wore woll formed. IhIs 18 shown on P1ste lo and 1-b. The photographs also whow that there vere no apparent differences in the growin of the oats Irom the different treatments. During the early growth of the crop a sl1ght stimalation was noticed in the pots recolving phosphorio acid as compared with the check pot receiving only nitrogon and potash, but th1s was soon equal1zed, probably due to the fact that oats aro coarse feeders and could obtain considerable plant food from the soll 1 tself after once gotting started. The addition of Ilme had no effect.

The dry weighto given in Table I show no uniform variations due to fert111zer treatment since any differences ghown may be due to natural variations in growth. 
Serles 1. Pot No.: duplicates: Auplicates: Oats Gren-ary meights in orams

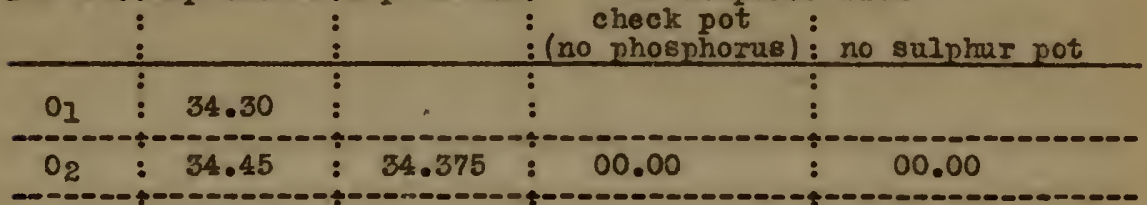

$\Delta_{1}: 37.00: \vdots:$

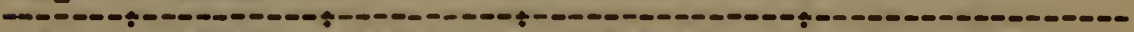
$\mathrm{A}_{2}$
35.60
36.30
$+1.925$
00.00

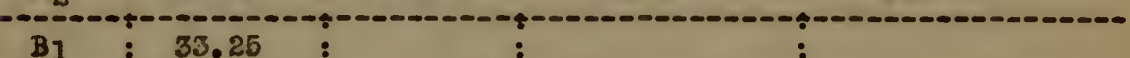

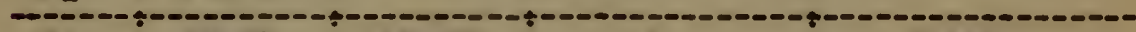

$\mathrm{B}_{2}: 32.50: 32.875:-1.5 \quad: 3.425$

$\mathrm{C}_{1}: 37.50 \div: 50$

$\mathrm{C}_{2}: 34.40: 35.95:+1.5750 .000-0.35$

$\mathrm{D}_{1}: 30.30 \quad: \quad 3$

$\mathrm{D}_{2}: 33.20: 31.75:-2.625:-4.55$

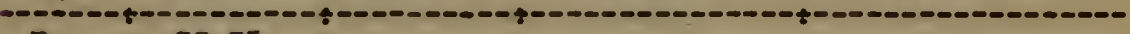

$x_{1}: 33.35:: \quad:$

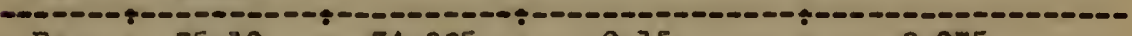

$\mathrm{B}_{2}: 35.10: 34.225:-0.15:-2.075$

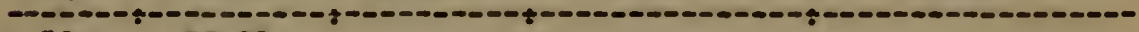

$\mathrm{LO}_{1}: 33.90: \quad: \quad:$

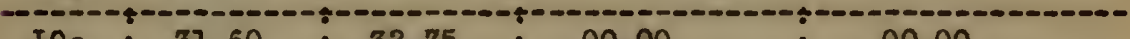

$\mathrm{IO}_{2}: 31.60: 32.75: 00.00 \div 00.00$

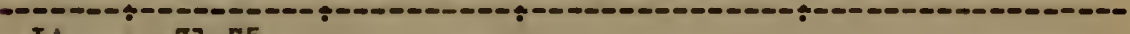

$\mathrm{IAA}_{1}: 31.75:$ :

$\mathrm{IAA}_{2}: 30.30 \div 31.025:-1.725: 00.00$

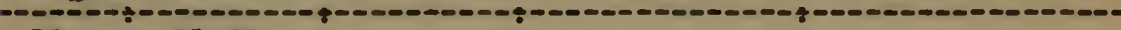

$\mathrm{IB}_{1}: 31.30: \quad:$

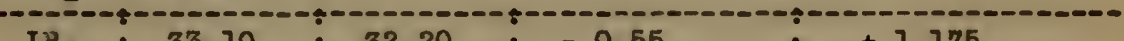

$\mathrm{LB}_{2}: 33.10: 32.20:-0.55 \div+1.175$

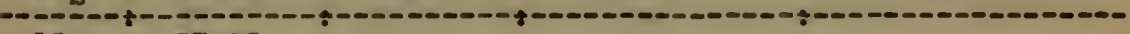

$\mathrm{LC}_{1}: 37.95: \quad: \quad:$

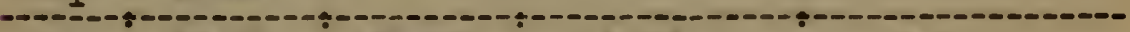

$I C_{2}: 33.10: 35.525:+2.775:+4.5$

-

$\mathrm{IDP}_{1}: 32.90:$ : :

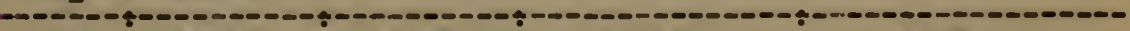

$\mathrm{ID}_{2}: 34.85: 33.875:+1.125:+2.85$

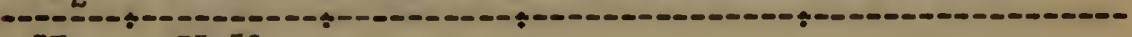

$\mathrm{LE}_{1}: 35.50:$ :

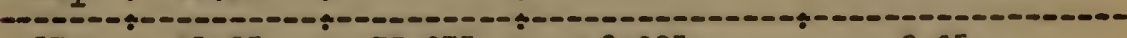

$\mathrm{LE}_{2}: 31.85: 33.675:+0.925:+2.65$

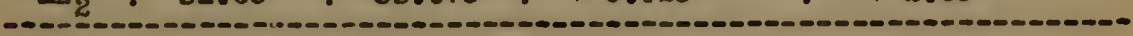


Osts do not seem to be affected by aprlications of sulphur fortilizors. Fhis agrees with the conslusions of other invertigators. The sulphar content of oats is known to be low so that only amall amounts of sulphur are usod in plant growth. Also. since the oat plant is a cosrse foodor it 18 probebly able to get sufficient sulphar from most any soll on which growth will take place at all.

Series 2. Turnirs.

(Seed sown January 29th. Crop harvested May 9th.)

Fros Plate 2 there appears to be very little difference in the grouth of the turnip plants under ifferent treatments. This was true throughcut their growing poriod.

But from Table II-b there are seen to be falrly constant variations in faror of scme of the sulyhur treatmats. There no I1me was applied all the sulphur treatmonta gave inoreased Jielo of both tops and roots. The calcium sulphate in the acld phosphate and the calcium onlphate added separatej.g gave larger increases than the sulpharle acld or flowers of salphur. This may have been partig due to the need of the soll for $11 \mathrm{me}$, but probably as wach lime was added in the double superphosphate as In the acid phosphate, and so the increase mast have been due in greater part to the sulphur added. The combined sulphur of the acid phosphate seems to be the nost beneficial form.

The irregular results from the addition of lime were partly due to infuries from aphids and purtly to the effect of the lime on the soll. The addition of lime evidently was needed by the soll and 1mproved it to such an extent that the check pota and no sulphur pots gave large ylelds themselves and so cut down any increase due to the other treatments. This does not deatroy the evidence in favor of the effect of sulphur on plent growth but 


\section{Table II-a.}

Series 2.

Turnips

Oven-dry wa1phts in prame

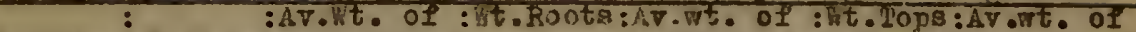
Pot No.: Wt. Tons:auplicetes: : dupl1cates:\& Ront s: dupl icates

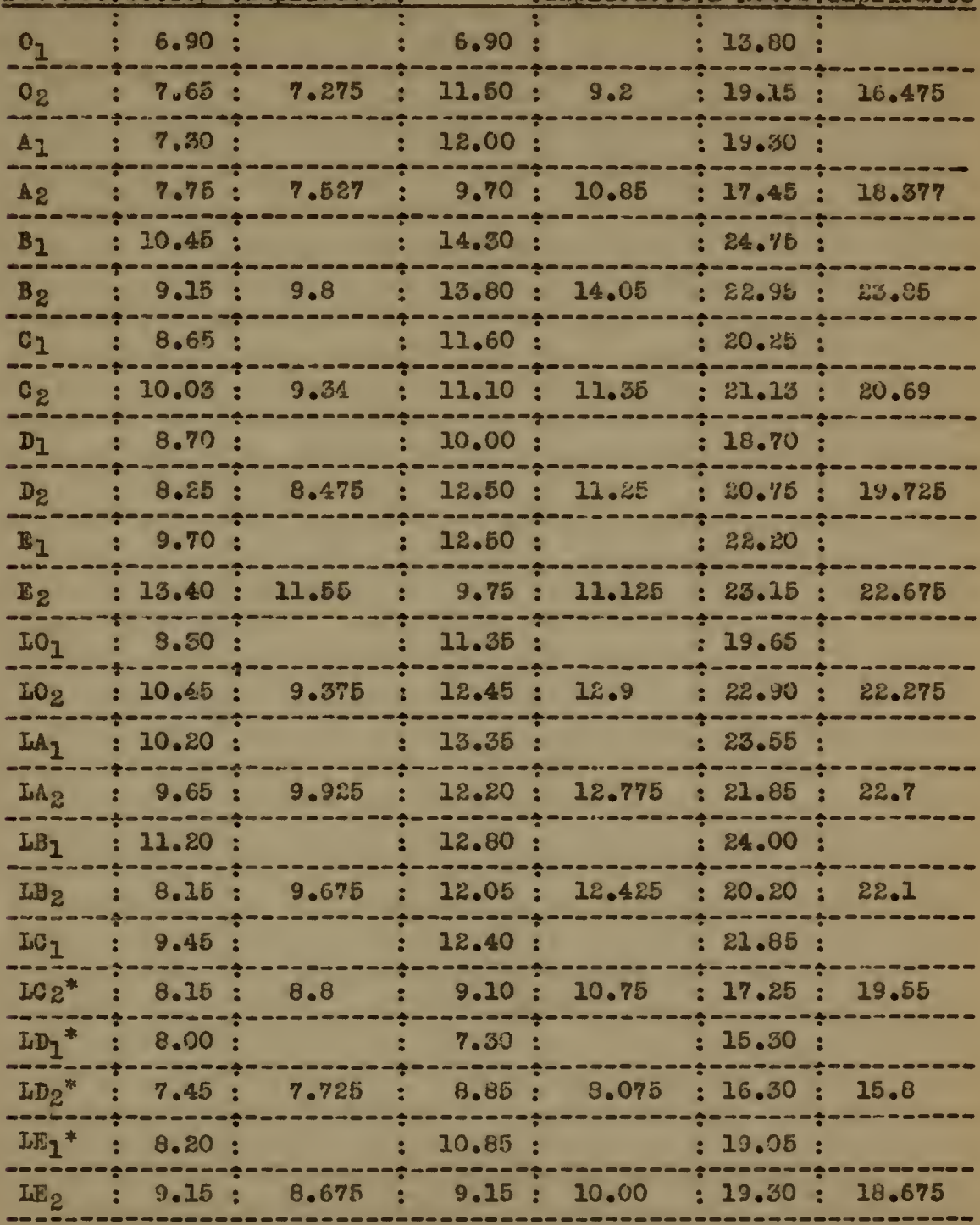

*Injurad by apride. 
Table II-b.

Series 2.

Tarnips

: Irerease + or kecreas - ae congared pith :Chock Pot. (NO phosphozus):: Ho suIphur Pot

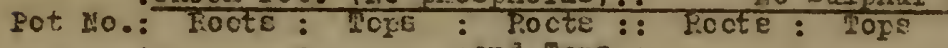

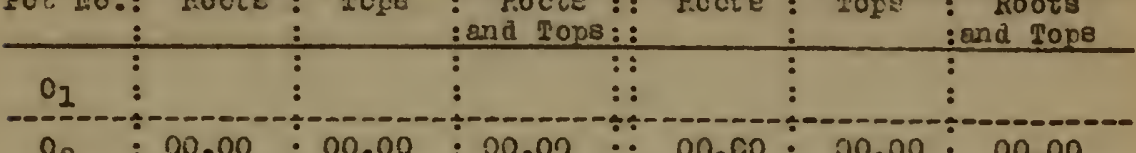

$0_{2}: 00.00: 00.00: 00.00:: 00.00: 00.00: 00.00$

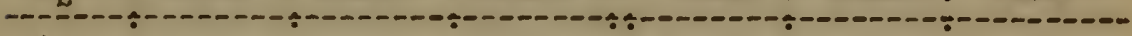

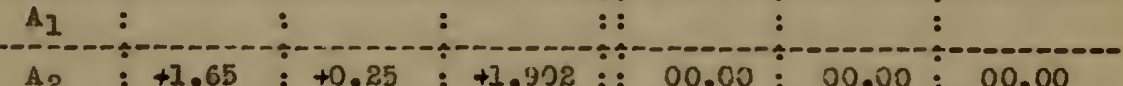

$\mathrm{A}_{2}:+1.65:+0.25:+1.322:: 00.00: 00.00: 00.00$

-

$B_{1}: \quad: \quad: \quad:$

$\mathrm{B}_{2}:+4.85:+2.525:+7.375::+3.20:+2.273:+5.47$

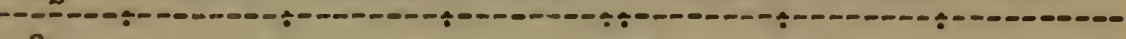

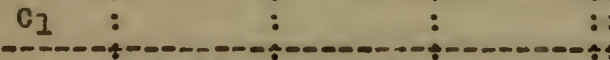

$c_{2}:+2.15:+2.065:+4.215::+0.50:+1.813:+2.31$

$C_{2}:+2.15:+2.055:+215::+0.50:+1.813:+2.31$

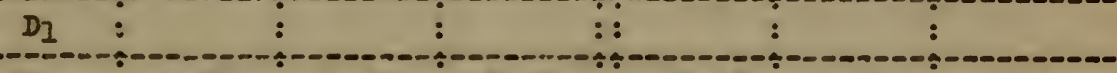

$D_{2}:+2.05:+1.20:+3.26::+0.40:+0.948:+1.35$

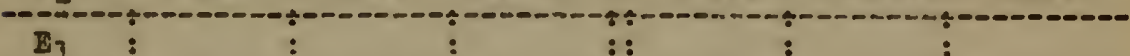

B $:+0.925:+4.275:+5.20::+0.275:+4.023:+4.298$

$\mathrm{E}_{2}:+0.925: 110295:+5000$

$\mathrm{LO}_{1}: \quad: \quad \vdots \quad$

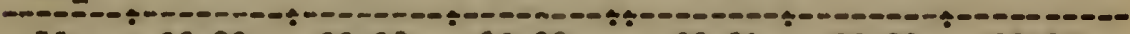

$\mathrm{LO}_{2}: 00.00: 00.00: 00.00:: 00.00: 00.00: 00.00$

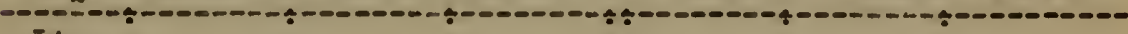

$\mathrm{IA}_{1}: \quad: \quad \vdots \quad:$

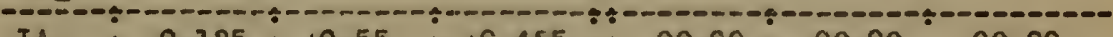

$\mathrm{TA}_{2}:-0.125:+0.5 E:+0.425:: 00.00: 00.00: 00.00$

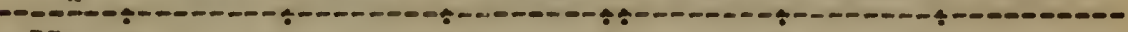

$\mathrm{LB}_{1}:$ : : : :

$\mathrm{IB}_{2}:-0.475:+0.30:-0.175::-0.35:-0.25:-0.60$

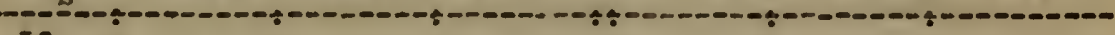

$\mathrm{LC}_{1}: \quad: \quad: \quad:$

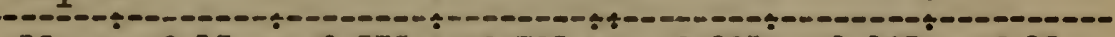

$\mathrm{IC}_{2}:-2.15:-0.675:-2.725::-2.025:-1.125:-3.15$

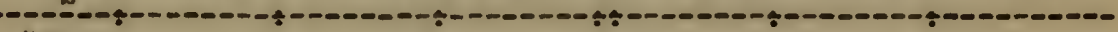

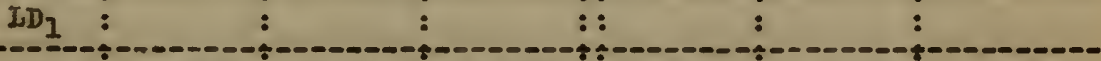

$L D_{2}:-4.825:-1.65:-5.475::-4.70:-2.20:-6.90$

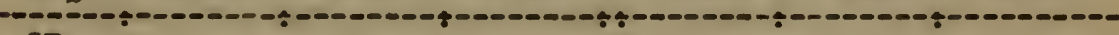

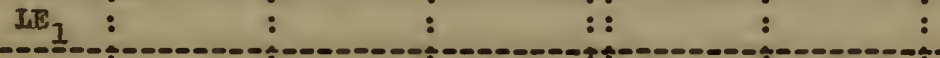

$\mathrm{IIE}_{2}:-2.90:-0.70:-3.60::-2.775:-1.25:-4.025$

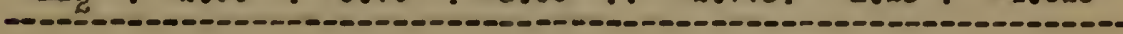


shows that an improved condition of the soll due to liwing wy allow tho plant to obtain sufficlent from the soll alone.

rurnip plants are known to be high anlphor consumers and th1s work showe that the sulphur contained in acid phosphate, or added in like amount, whon used as a fertilizer is an aid in causIng increased growth.

Sor109 8. Clover.

(Seed oom January 318t. Crop harrested kay 15th.)

The groath of clover plants did not show umeh variation due to different fertilizer treatments as can be seon from Plate 3. A slightiy heavier growth is noticeable, however, in some of the pots roceiving 11me. Fhis shows that the so12 was in neod of $11 \mathrm{me}$.

However, the variation in dry weights does show a congtant incrsase over the ohecks due to the various sulphur treatwents on both the 11med and unlimed solls. This 18 seen from the figures in Table III.

The different forms of sulphur applied in amounts equal to that in the ac1d phosphate do not show any constant alfferences in their effect on plent growth. For clover the combined oulphar in the ac1d phosphate does not seem to be the best while for tumips 1t doos. Calciom sulphate and aulphuric acid seem to bo the best for olover where no lime wes used. Fith $11 \mathrm{me}$ the flowers of sulphur gave the largest inerease. The balance of the ovidence seoms to be in favor of the sulphur combined as calcium sulphate in the acid phosphate. Caloium aulphato added seperately is next in beneficial effect. This is probsbly beceuse the flowers of sulphur need to be oxidized to sulphates before they are of use to the plant and the oulphurio ac1d must be taken up by a base. The calcium sulphate applied as such is 


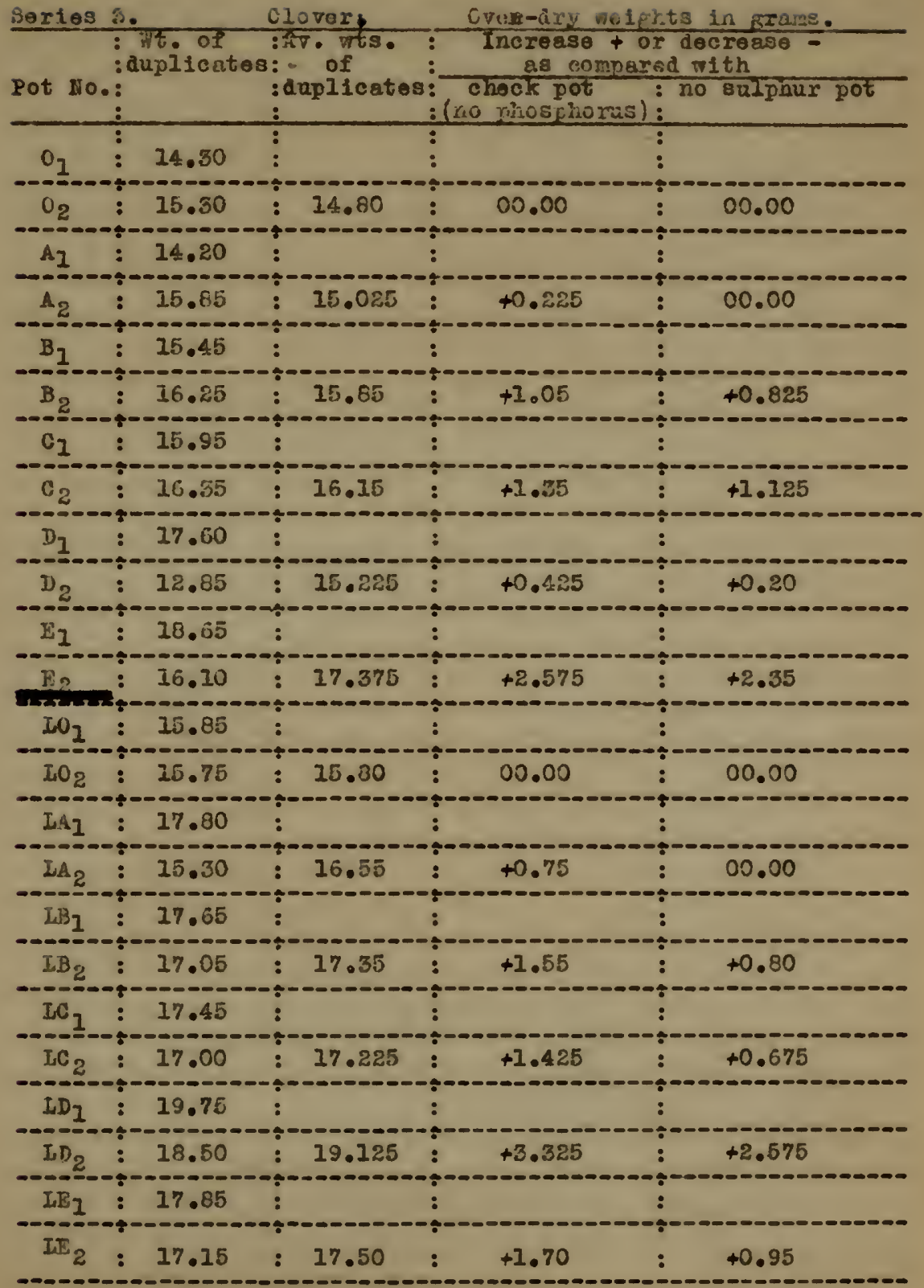




$$
-50-
$$

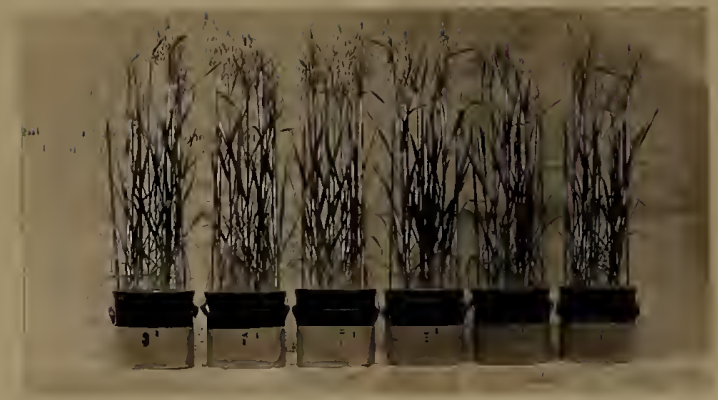

Plete 1-2.

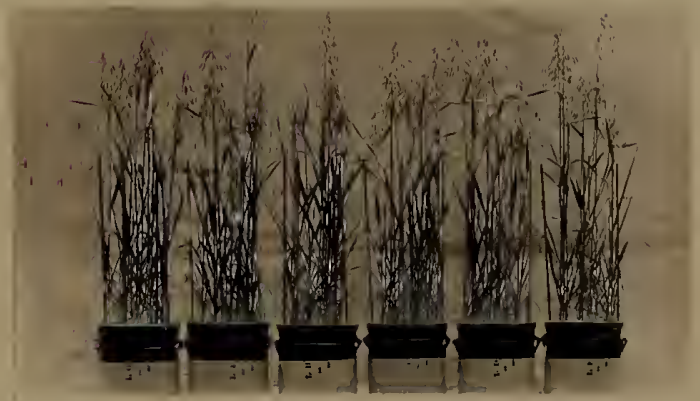

PIate I-b. 
21ato 2.

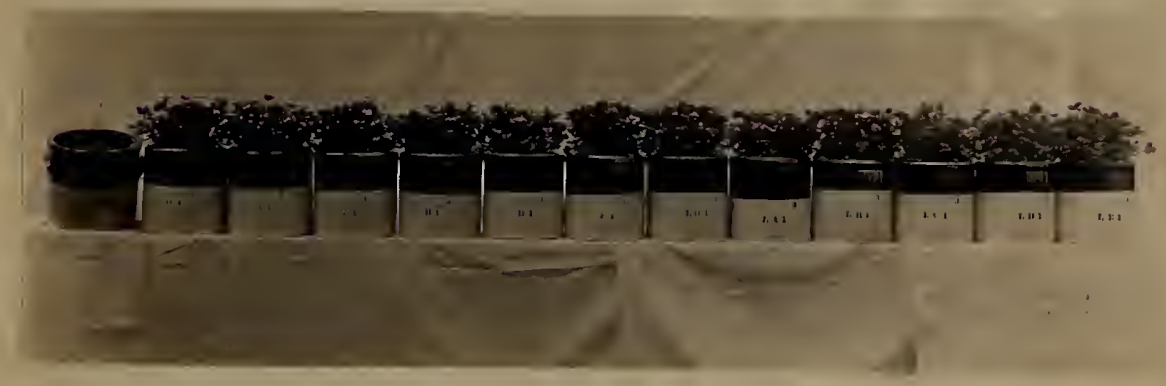

Plato 
ready at once for solution and absorption by the plant.

Clover is knom to contain a mealum percontage of sulphur. chieng in 1 te protein compounds. The above eridence shows definitely that the aulphur contained in acid phosphate when applied to clover as a fertilizer alds the phosphoric acid in giving increased giolds. It is therefore important to euch crops that an adequate supply of available sulphate should be maintained.

\section{Fater Soluble sulphates in the Soll.}

In an effort to determine to what extent soluble sulphates are formed in the soll and used by the plant. an analysis of the alferently treated solls was made for water soluble sulphates. This was done for each treatment of the turnip and clover crops. Two analyees were made one month apart to ascertain any exhaustion of the sulphate oupply through use by the plant.

The method of anelysis was similar to that outlined by Brown (26)

and Kollogg. Mifty erans of oven dry soll wore placed in a shaker bottle with $100 \mathrm{c.c}$. of distilled water and shaken for seven hour in a shaking machine. This was filtered and 1 c.0. of conc. hydrochlorio acid aded to flocculate the collolas and to wake the solution acid. After eottling, this wes filtered and the piltrate made up to 500 c.c. In a volumetric plask. An aliquot of $300 \mathrm{c.c}$. Was teken from which the eulphates were proc1pitstod as barium sulphate in a not solution by the addition. drop by drop. of $10 \mathrm{c.c}$. of hot barium chloride. The hot solution was allowed to stand over a hot water bath for about twontyfour hours. The precipitate was then filtered though a Gooch cruolble of known weight. The cruolblo and preoipltate was allowed to dry and then heated to a red heat orer a bunsen flam for about a half hour. After cooling in a dessicator. It was 
wolghed and the amount of barium aulphate determined by oubtraction This anount was calculated as sulphur trioxide and expressed as parts per 100,000 of dry s011.

A oomposito co11 semplo for analyeis was taken from each of the duplicate pote.

The results obtalnad for the turnip pote are given in rable IV. The figures do not seem to be uniform, dee probably to varlations in aampling. Also, the differences botween amounts of alphates obtained were so amall that diffeulty was experienced In filtering and Folghing then accurately.

There Beome to be but little correlation between amount of water soluble sulphates and plant growth. Injom cases the amount obtained where no sulphate fertilizera vere applied excoeds the amount from sulphate treatod so118. This may hsve boen due to optirum conditions in the soil for the formetion of enlphates but not for a good crop growth, due to the lack of phosphorus. For this reason, a smaller amount of sulphates would be taken up by the plant.

The water soluble anlphate content of the original soll 18 seen to be wuch less than that of the pot 8011 after growing a crop for some time. This 19 probsbly due to the lack of arainage from the pots and the prevention of loss by leaching which would occur in the field. Some sulphates wore also added in the tap water but the amount was noglibible. A composite ample of all the tap water usea anolyzed 0.2777 parte sulphar^per 100,000 parts of water. This gives a total addition to each of the turnip pots of about 0.039 grams sulphuriand to each of the clover pots of about 0.041 grams.

A decrease in amount of water solnble sulphates is plainly apparent after a months growth of turnips. This month'a growth 
Taiblo IV.

Water soluble sulphates. Expreased as $\mathrm{SO}_{3}$ parts per 100000 of 8011 Series 2. April 10. :: Series 2. Lay 8.

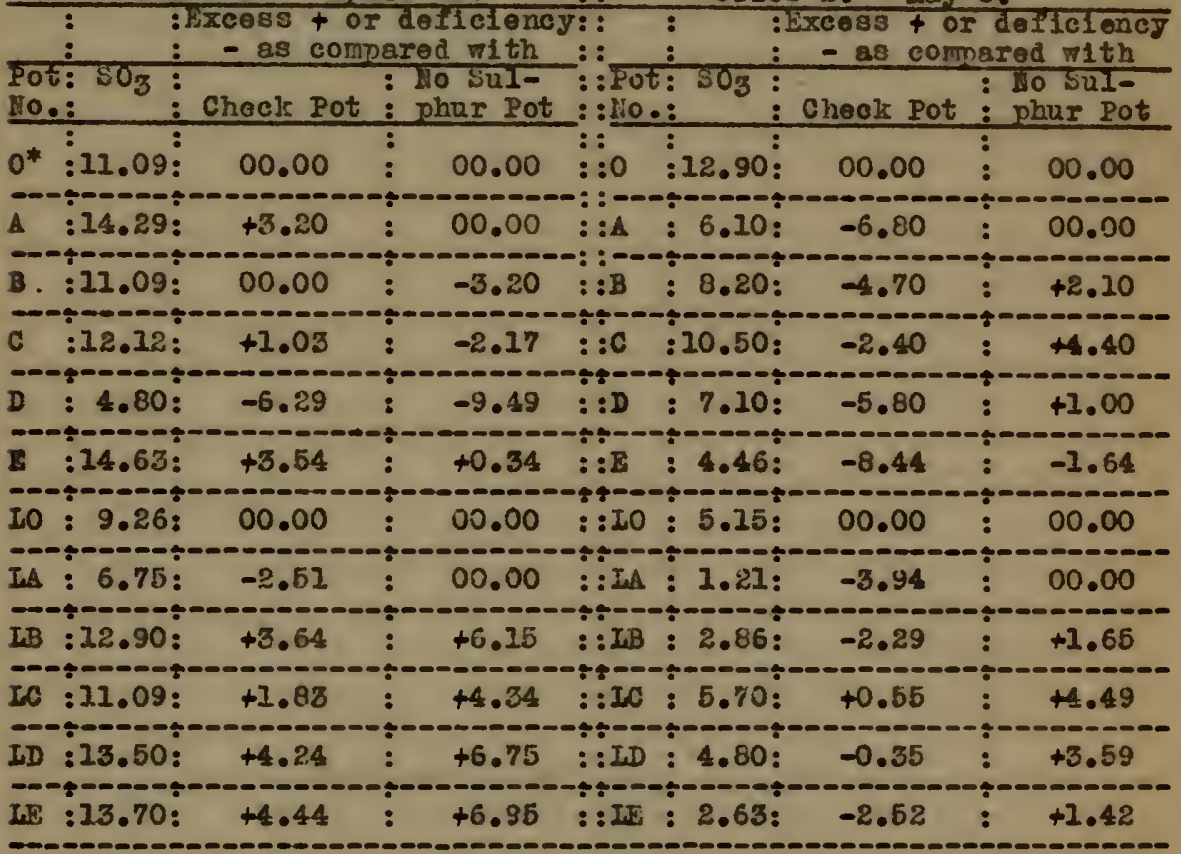

*4.23 parts per 100000 originally contalned in zo1l used. 
rable Y.

Vater solublo sulphates. Expressed as 303 parts per 100000 of 8011

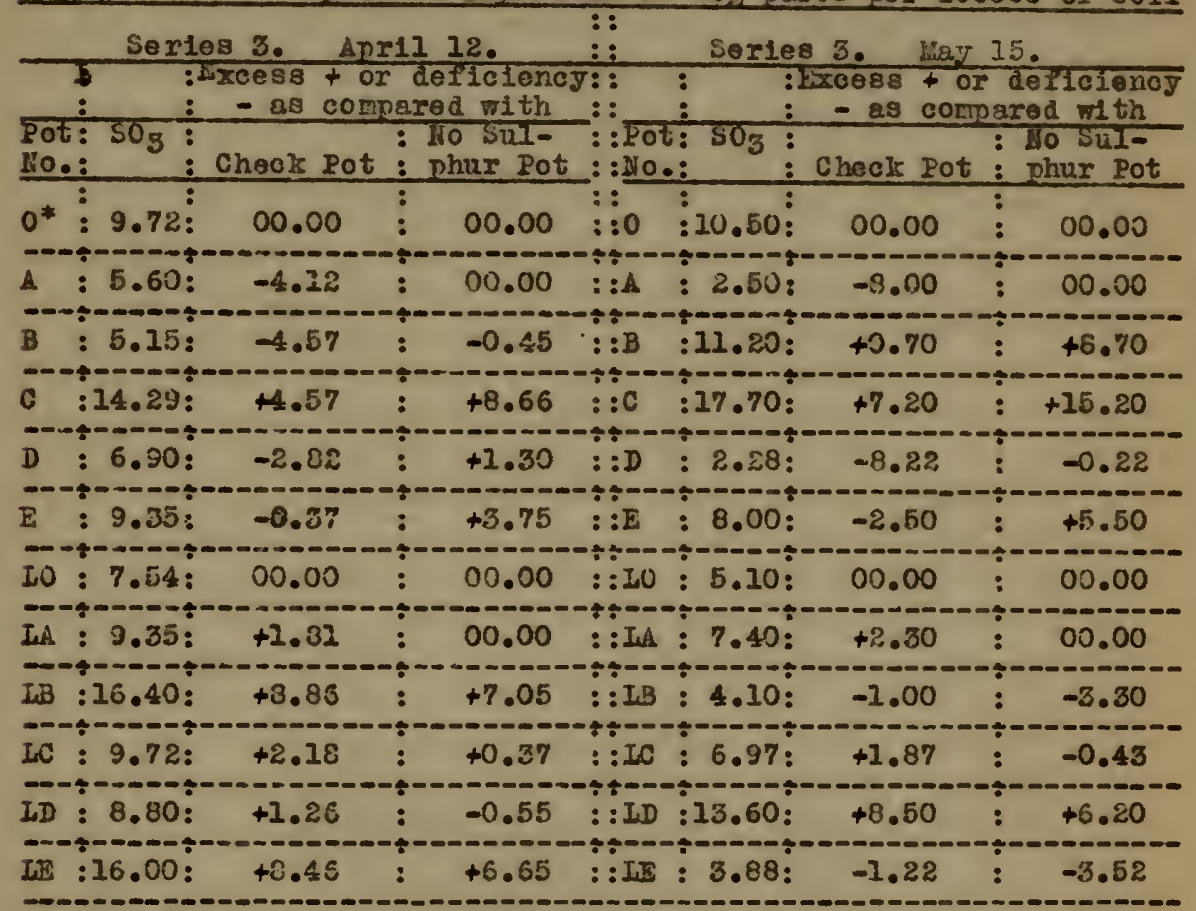

*4.28 parts per 100000 criginally contained in soll used. 
took place during waturity when the ereatest comand for sulphates would come from the plant. It seene then that a crop, such as turnips, containing a high porcent of sulphux, does use up the readily available aupply of anlphates in the 8011.

Table $\nabla$ showe very little correlation between the srowth of the olover plants and tho amount of water soluble sulphate prosent from different treatments. As in the case of the turnips, somo pots without any sulphate treatment show as high soll content of water soluble sulphates as those receiving treatments with sulphates.

The clover pots do not show as decided a decrease in the content of water soluble oulphates at the end of the month as the turnip pots do. There 18, however, a slight decrease. Thls shows that a crop auch as clover, containing a modium percent of salplar, does use up the readily available sulphates but not to as great an extent as the turnip crop. 


\section{SUICARI AHID COHCLOSIONS.}

The possibility of sulphur'g becoming an important limiting factor in crop production has but recently come prominently to the attention of agricultaral investigators. The wort of various men has brought out numerous pointa.

1. Improved methods of aulphur emalysis for crops and e011s show that large amounts of eviphur are removed by crops and that the total per cent in solla 19 grodually deoreased by continual cropping.

2. Salphur exiets in the soll in various forms which aro changed to the aulphate form by bacterial and chemical action. It 18 chleriy in this form that anphur is taken ap by tho plant.

3. Crops vary in their demand for sulphur according to thelr composition. Experiments have shown that expecially those crops having a high sulphur content are benefited by applicationa of sulphur fert1l1sers.

4. Sulphur may have an indirect as well as a direct offect on plant growth but the direct effect as a plant food 18 important.

5. Aside from the loss of anlphur from the soll by removal In crops, the ready solubility of sulphates allows a large 108 in drainage watera.

6. The chief sources of supply of sulphur to the soll are rainfell, atock manure and commercial fert1lizers.

7. Figures ahow that the stock manure producod in ang typo of farming is not sufficient to maintain a permanent oulphur supply in cropped Bo11s.

8. Commercial fert1lizer, as applied in common practice on 
Iev England farms, aro ohown to furmish a large excese of eulphur Ior crop use. Therefore, there is no danger of aulphur's becoming a limiting factor in crop production where commerclal fert1lizers are commonly used.

From the experiments performed. the followine conelusions may be drawn:

1. The sulphur in acld phosphate when applied to soil of a Iow oulphur content has a beneficial influence on the growth of clover and turnips but produces no effect on the erowth of oats. 2. Sulphar is most Iikely to be benoficial to the growth of crope contalning a medium or high percentage of alphur.

3. The data obtained 1ndeate that the eupply of water soluble sulphates in the ooll 1s decreased as the plant Brows.

4. Ac1d phosphate has a benelicial action on plant ercrth. due to the use of 1 ta sulphur as a plant food. 


\section{BIBIIOGRAPIXX}

(1). Sarssure, Theodore de,

(2). Bousa1ngault, J. B.,

(3). Dary, Humphry,

(4). Sprengel, Carl,

(5). Iiobig. Juatus,

(6). Hart \& Peterson,

(7) . Drggar, B. M.,

(8). Lou, Dr. Oscar.

(9). Bogdanov,

(10). shedd, O. M..

(11). Clark, F. V.,

(12). Dymond, Kiughes \& Jupe.

(13). Swarison M M11er.

(14). shoda, 0..u.,

(15). Robinson, T. 0. .

(16). Brom \& Xellog8,

(17). Ames B Boltz.

(18). H1lgara,
Recherches chimiques sur 10. Vogetution, 1804. Paris.

Beonomie Rurale consideree dans sez Rapports avec la chimle, la Physigue, ot la foteorologio, 2nd. od., 1851. Patio.

Hilements of AEricultaral Chemistry. London, 1813.

Chomle fur Landuirthe, Porstmännor and Cameraliaten, Götingen, 1832.

Chemietry in Its Application to Agriculture and Physiologs. 18t. od. $184 \mathrm{a}$

Sulphar Requirements of Pare Crops in Relaticn to So 11 and AIr Supply. F18. Research Bul. 14. Apr., 1911.

Plent Physiology, p. 182.

P. P. I. BuI. 45, 1903.

S. S. R. 11 : 723 .

Tho Felation of Sulphur to soll Fert111ty. Ky. Bal. 188, Dec., 1914.

Data of Geochemistry, 1908. U. S. Geo1. Survey, BuI. 330, p.26.

Sclence, Vol. 1, Prt. 1, p. 217, 1905. Sulphur in Kansas So118. Soll selence, Deb., 1917. Vol. III, Ho. 2.

The Sulphur Content of some Tupical Kentucky solis. $\mathrm{Ky}$. Bul. 174, Sopt., 1913.

Analyses of some typical American So118. U.S.0.A. Bul. 122.

Sulphur and Soll tert1lity. A.S.A. Vol. 7. No. 3, 1915.

Sulphur in kelation to So11. and Crops. Ohto Bal. 292, Mar., 1916. S0118, p. 344. 
(19). Buthelot \& Nadre,

(20). Peterson, 曹. H.

(21). Kappon, H. Von \& Quenseil, B..

(22). Brioux, Ch. \& Guerbet, h.

(23). Iossovich, P. S.

(24). Dercolon, A.,

(25). Iipman, J. G.,

(26). Brom \& Telogg,

(27). Hart, E. B. \& Pottingham, E.

(28). Puley, F. L.,

(29) . ReIter, F. C.,

(30). Reimer, R. C.,

(31). I1pman, Blair, Opren \& Volean.

(32). Pitz, Walter.

(33). Brom, P. D. 2 Johnson, H. R..
Ann. Chem. Phye., 1892, 25:305.

Porms of Sulphar in Plant Materials and Their Variation vith the soll Supply. J. Nrer. Chem. Soc., 1914, XxxivI, 1290-1300.

Űber die unwandalungen $v$ cos sohwefel und schwefelverbindungen in ackerboden. Landin. Vors. Stat. 86, 1915.

1913. Evolution du soufre dane le gol, otude sux son oxydation. R.S.R. $30: 222$.

On the ciroulation of sulphur and of chlorine on the earth, and on the importance of this process in the orolution of solls and in the plant world. Chom. Abst., 8 : 978 .

Jour. Chem. Soc. (Londan) 1913, CIV: 579. E.S.R. 26 : 819,

The oxdation of sulphur in the so11 as a moang of inoreasirig the avallability of mineral phosphatea. Soll Sclenoe, Vol. I, Ho. 6, Jun., 1916. Soll selence, Vol.II, No. 6, Deo.,1916.

Sulfolicstion in $8011 \mathrm{~s}$. IOwa Reserroh Bul. 18, Dec., 1914.

Relation of sulphur compounds to plant nutrition. Jour. Agr. Researoh, vol. v, No. 6, Hov., 1915 .

Rolation of sulphur to soil productir1ty. A.S.A., Vol. B, No. 3, 1916.

sulphur fortilizer for alfalfa. Pac1fle Fural Press, June 27. 1914.

Sulphur as a fertilizer for alfalfa. Bullotin, Cal. State Como. of Hort1culture, sopt., 1915.

N. J. Sta. Rpt . 1912, p.p. 270-277.

Effect of elemental sulphar and of caloium sulphate on certain of the higher and lower forms of plant life. Jour. Agr. RoBearch, Vol. 5, No. 16. Jan. 17, 1916. 
(34). Plelffer \& Blarck,

(35). Pfeiffor \& sirunormacher.

(36). Pred, E. B.,

(37). Shorbakoff, C. D.,

(38). Whe eler, Hartwell \& lisoore,

(39). Hopikins,

(40). Hopkins,

(41). Hopkins,

(43).

(44). 씨고.

(45). Is obig, Justus,

(46). Hopk1n8, C. G..

(47). Brod, K. B. Hart, E. B.,

(48). Demeion, A..

(49). Derpolon, A.,

(50). Granretto, F.

(51). Takreuchi,

(52). Janicaud,

(53). Rabate, E..
Jandw. vers. stat. 83, 1914, p. 359. Pâhlings Isandw. Ztg. 64 (1915), No. $9-10, p \cdot p \cdot 243-255$, 118 . 1 .

kelation of $\mathrm{CS}_{2}$ to $\mathrm{oll}$ organisms and plant growth. Jour. Agr. $h_{0-}$ search, Vol. VI, No. 1. ApI. 3. 1916.

Potato seab and sulphur alsinfection. 1914. K. Y. Cornell bul. 350, p.p. $741-743$.

R. I. 12th. Ann. Bpt., 1899, p.p. 163-1є7.

Soil Pertility and Permanont Agriculture. R. I. Bul. 114, p. 271 .

So11 Fert1lity and Permaner.t AEr1cuIture. R. I. BuI. 114, P. 4.23.

sul1 Rext111ty and Yermanent Agriculture. R. I. Bul. 114, p.p. $442,4.48$.

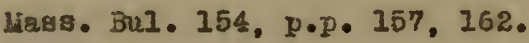

s011 Iertiity and Permanent Agr1culture. R. I. Bal. 114, p. 533 .

Chemistry in its Application to Agriculture and Physiology, 1840, p. B4.

The Sulphar Supply of the soll. Breoder's Geretto, Vol. 60. Ho. 2, 1911, D.p. 51-52.

The Comparat170 Effect of Phosphates and Sulphates on Soil Bacteria. W18. Research Bul. 35, June, 1915.

E. 3. R. 26 : 819.

Jour. Chem. Soc. (Londor) 1913. V. CIF, 1579.

Bo1. Quend. Soc. Agr. Ital. 17 (1912) \$o. $14, p \cdot p \cdot 425-429$.

BuI. CoI. Agx. Tok10 Imp. Un1V. 7 (1908), 110. 5, p.p. 583-537.

Gartenrelt 18 (1914), No. 3, p.p. 29-32.

L. S. R. 30 : 441 . 
$-62-$

(54). Chanoxia \& Deariot.

(55). Ghancrin Deפriot.

(56). Heinzo. B.

(57). Sabasknikov, V. V.,

(58) . Boullanger. E.

(53). Boul1anger, $B$. Dugardin,

(60). Dalkahara,

(61). Bornhard,

(62). Bernherd.

(63). Magnien.

(64). Iritichler,

(65). von Fe1letzen, H.

(66). Suchting.

(67). Carlier. A.

(68). Carl1er, A..

(69). Z0112. D.,

(70). Uajzeres.

(7i). Heringor.

(72). Glanitto, E.

(73). Lierlice,

(74). Urben, Joser.

(15) . Nhalau, F.

(76). Cercelet, M.

(77). Chauz1t.

(78). Llechti.

(79). Vermore1. \& Dantory.
R. S. R. 25 : 519.

L. S. R. $29(1913)$ : 2.15 .

F. S. R. $28: 726$.

F. S. R. $28: 726$.

Chem. Abst. $6^{10}: 1332$.

Jour. Chow. Soc. (Iondon) 1912. V. CII : 971.

B. S. R. 19 : 1022 .

E. S. R. $23: 744$.

E. S. R. $27: 422$.

E. S. R. 30, Mo. $2: 138$.

E. S. R. 29 : 319 .

E. S. R. 30, 110. 2 : 139.

Cher. Abst. 1 : 1754 (1907).

Chem. Abst. $5: 2687$.

Chem. Abat. $5: 3116$.

Rev. Gen. Sc1., 26 (1915), Ho. 4. n.p. 120-121.

Cher. Abst. 5 : 3872 .

Chem. Abst. 6 : 1201.

Chem. Abst. Amer. Chem. Soc., Vol. 7. p. 1254 .

Chem. Abst. Amer. Chom. Soc., 7. H. 16 : 2823.

chom. Abst. 7 : 3685 .

Chem. Abst. $7: 4038$.

Chom. Abst. Amar. Chom. Soc., Vol. 7. p. 529 .

Chem. Abgt. Arer. Chem. Soc. 8, Io. $8: 1482$.

Chem. Abst. $8: 774$.

Chom. Abst. Amer. Chom. Soc . 8, Ho. $3: 545$. 
(80). Degrully.

(8I).

(82).

(83). Lyon \& Bizzell.

(84). Ruprecht \& Lorse,

(85). Ha.21, A. D.,

(86). Ha.1, A. D.
Chom. Abst. 6 : 1649.

Unpublishod data furnishod by $\mathrm{J}$. B. B. Hart of V18consin.

Unpublished.

The Loss of Sulphur in Drainsge

Water. Jour. S. S. A., Vol. 8, No. 2. 1916.

The Effect of Sulphate of Aramonia on S011. Yass. Exp. Sta. 28th. Ann. Rpt., Part 2, p. 72 .

The So1I, p. 222.

The Book of the Rothamsted Experiments, $p \cdot p$. 237-239. 
